
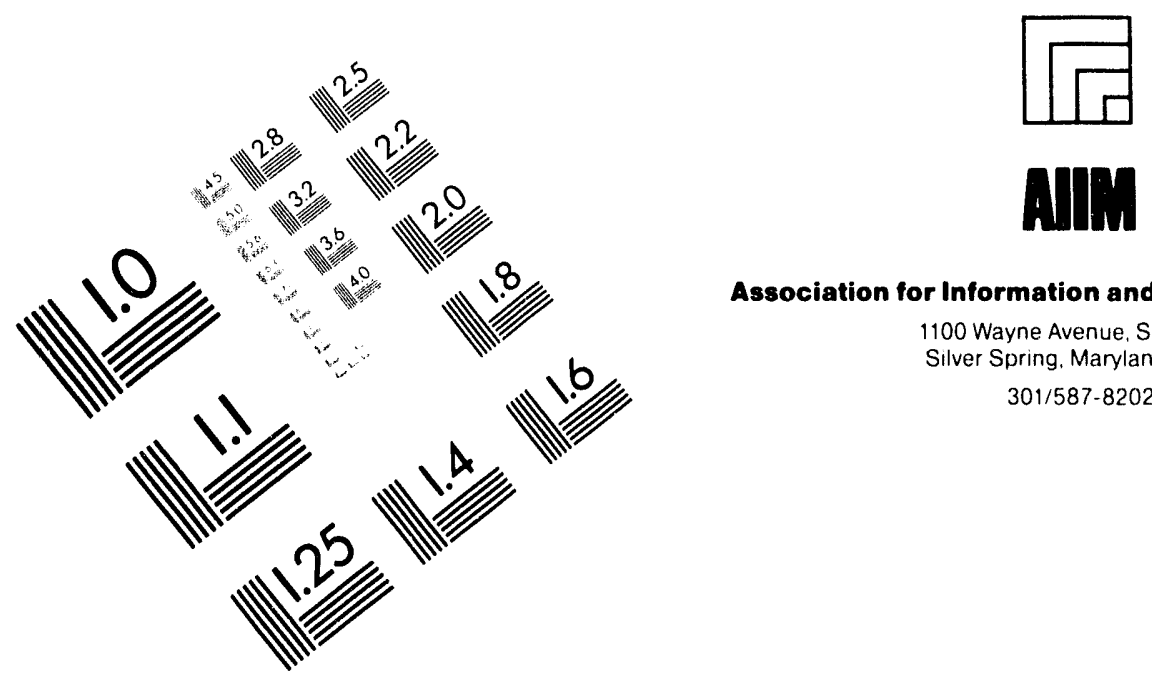

Association for Information and Image Management

1100 Wayne Avenue. Suite 1100

Silver Spring, Maryland 20910

301/587-8202

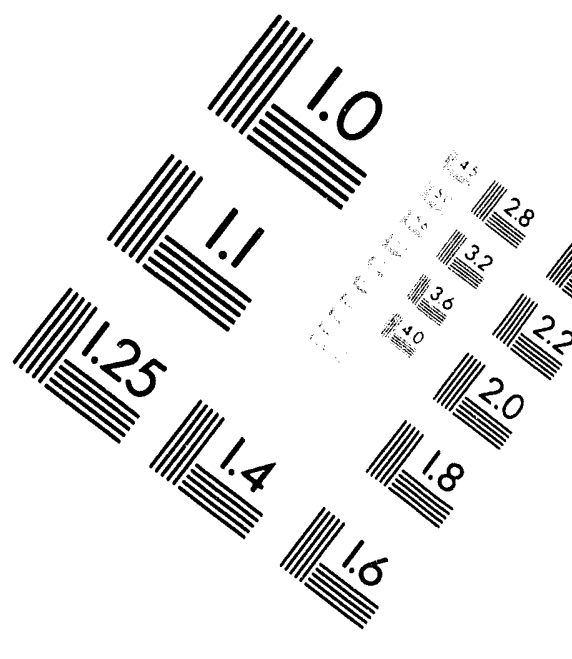

\title{
Centimeter
}

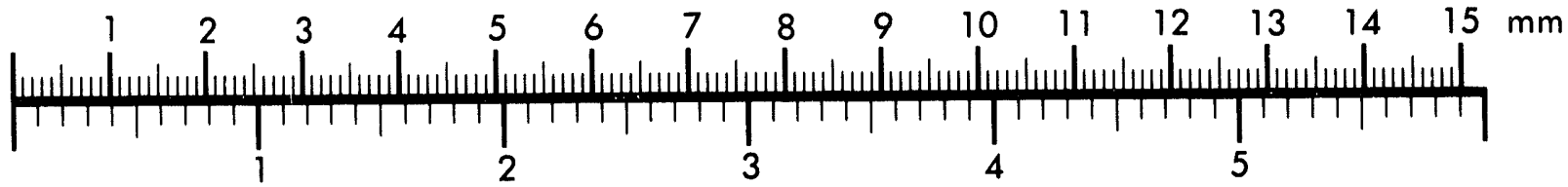

Inches
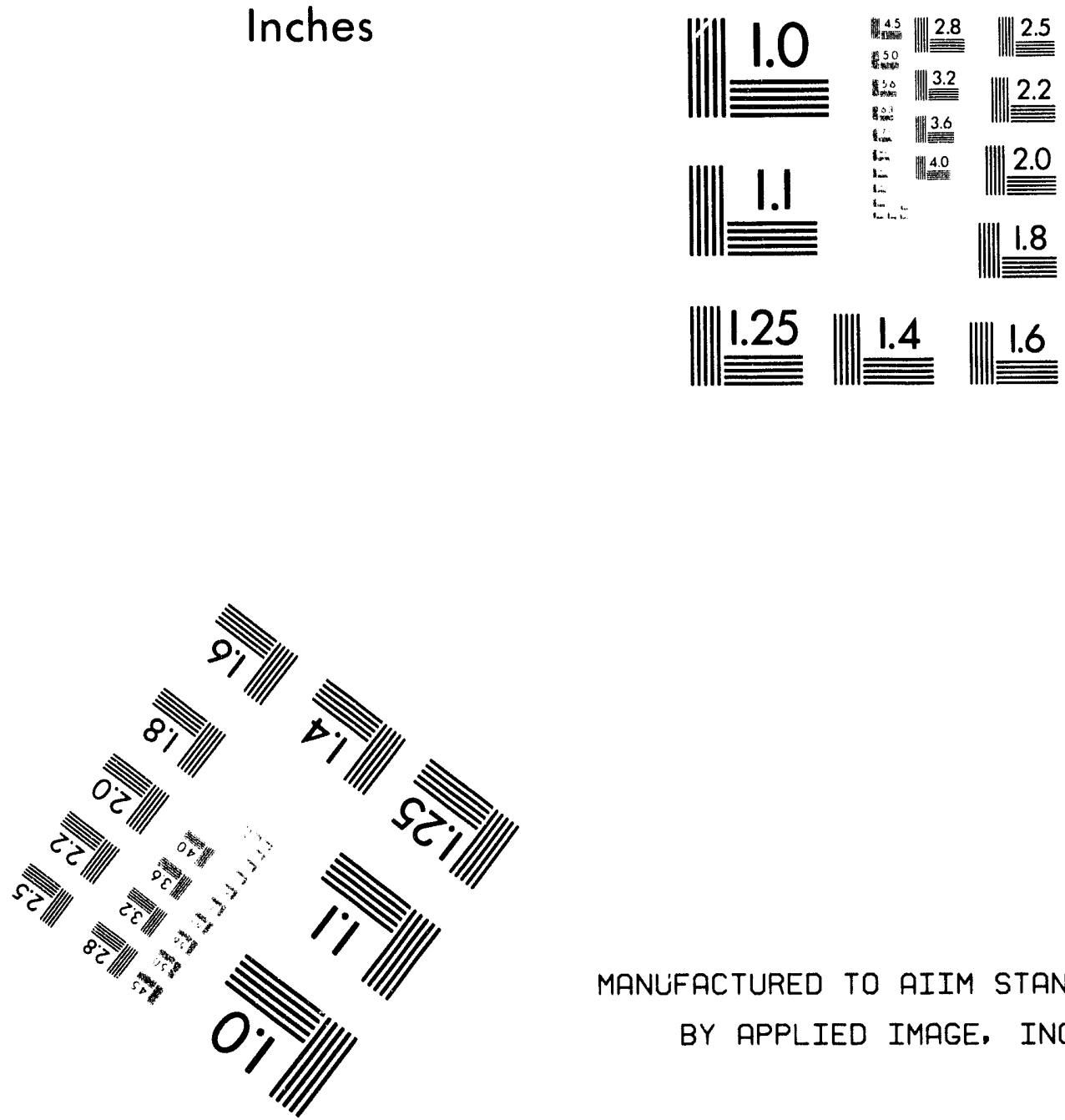

MANLIFACTURED TO AIIM STANDARDS

BY APPLIED IMAGE, INC.

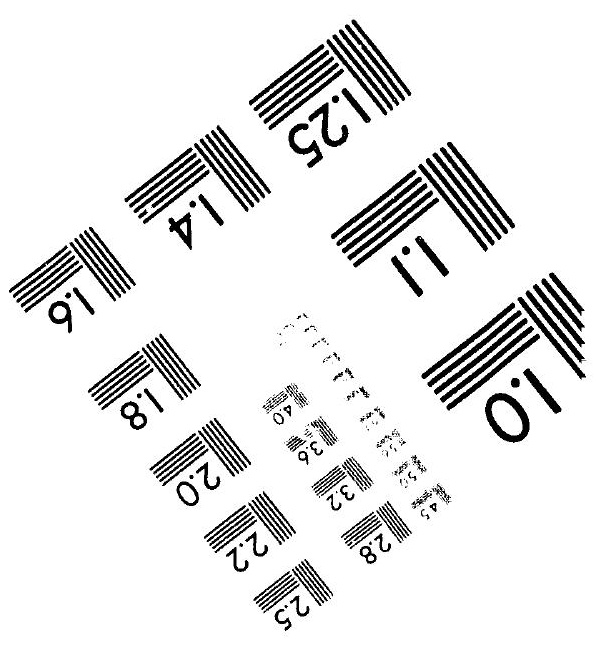



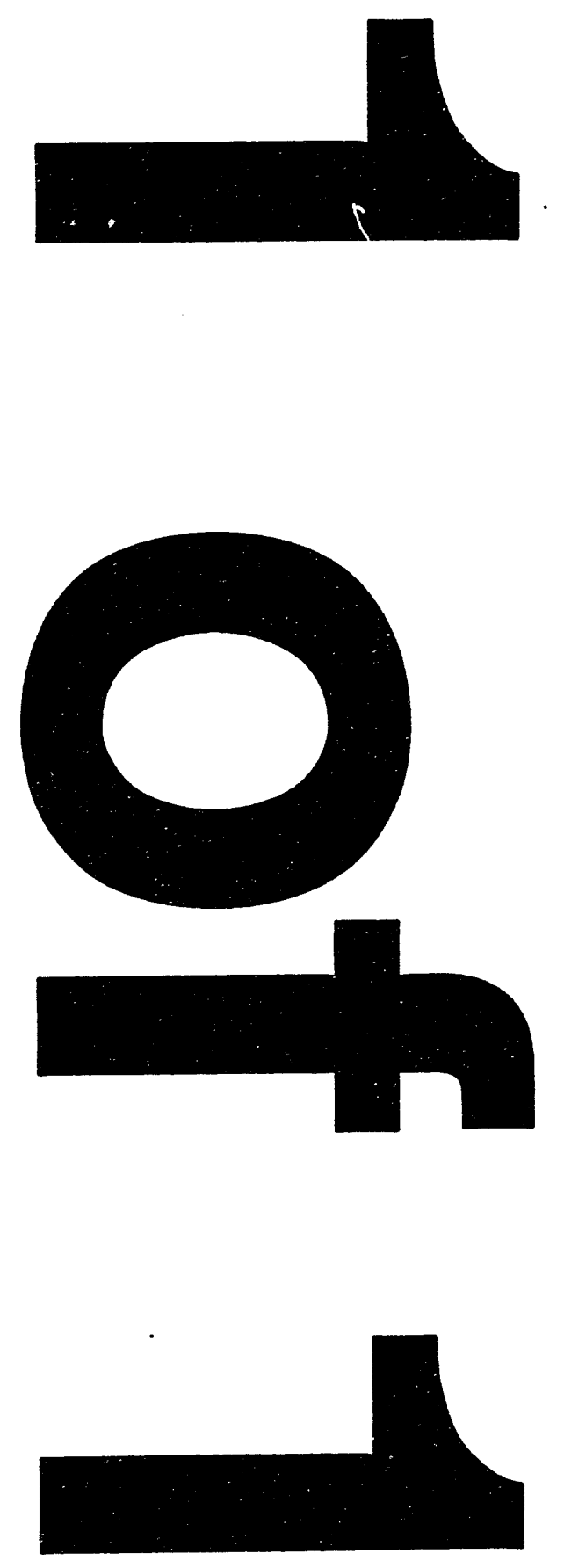
DOE/RL-93-105

Revision 0

\section{Pilot-Scale Treatability Test Plan for the 200-UP-1 Groundwater Operable Unit}

Date Published

May 1994

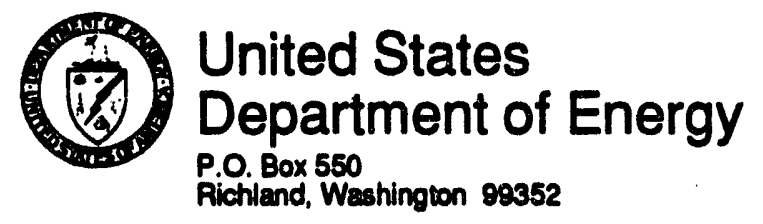

Approved for Public Release 
DOE/RL-93-105

Rev. 0

\section{EXECUTIVE SUMMARY}

This document presents the treatability test plan for pilot-scale pump and treat testing at the 200-UP-1 Operable Unit. This treatability test plan has been prepared in response to an agreement between the U.S. Department of Energy, the U.S. Environmental Protection Agency, and the Washington State Department of Ecology, as documented in Hanford Federal Facility Agreement and Consent Order (Ecology et al. 1989a) Change Control Form M-13-93-03 (Ecology et al. 1994). The agreement also requires that, following completion of the activities described in this test plan, a 200-UP-1 Operable Unit interim remedial measure (IRM) proposed plan be developed for use in preparing an interim action record of decision (ROD). The IRM Proposed Plan will be supported by the results of the testing described in this treatability test plan, as well as by other 200-UP-1 Operable Unit activities (e.g., limited field investigation, development of a qualitative risk assessment). Once issued, the interim action ROD will specify the interim action for groundwater contamination at the 200-UP-1 Operable Unit.

The approach discussed in this treatability test plan is to conduct a pilot-scale pump and treat test for the contaminant plume associated with the 200-UP-1 Operable Unit. Primary contaminants of concern are uranium and technetium-99; the secondary contaminant of concern is nitrate. The pilotscale treatability testing presented in this test plan has as its primary purpose to assess the performance of aboveground treatment systems with respect to the ability to remove the primary contaminants in groundwater withdrawn from the contaminant plume.

Implementing the pilot-scale treatability test system described herein will allow information to be gathered on the effectiveness, operating parameters, and resource needs of pump and treat as a potential interim action alternative. The overall scope of this test plan includes:

- Description of the pump and treat system to be tested, as well as the test performance objectives and data quality objectives that will be used to evaluate the effectiveness of the pilot-scale treatment system.

- Discussion of the treatment technology to be tested and supporting development activities, including laboratory treatability tests; process flow and conceptual design descriptions; and equipment, fabrication, utility, and system startup needs.

- Description of pilot-scale treatment system performance, operating procedures, and operational controls, as well as anticipated monitoring activities, analytes, parameters, analytical procedures, and quality assurance protocols.

- Summaries of other related treatability testing elements, including personnel and environmental health and safety controls, process and secondary waste management and disposition, schedule, and program organization. 
DOE/RL-93-105

Rev. 0

\section{ACRONYMS}

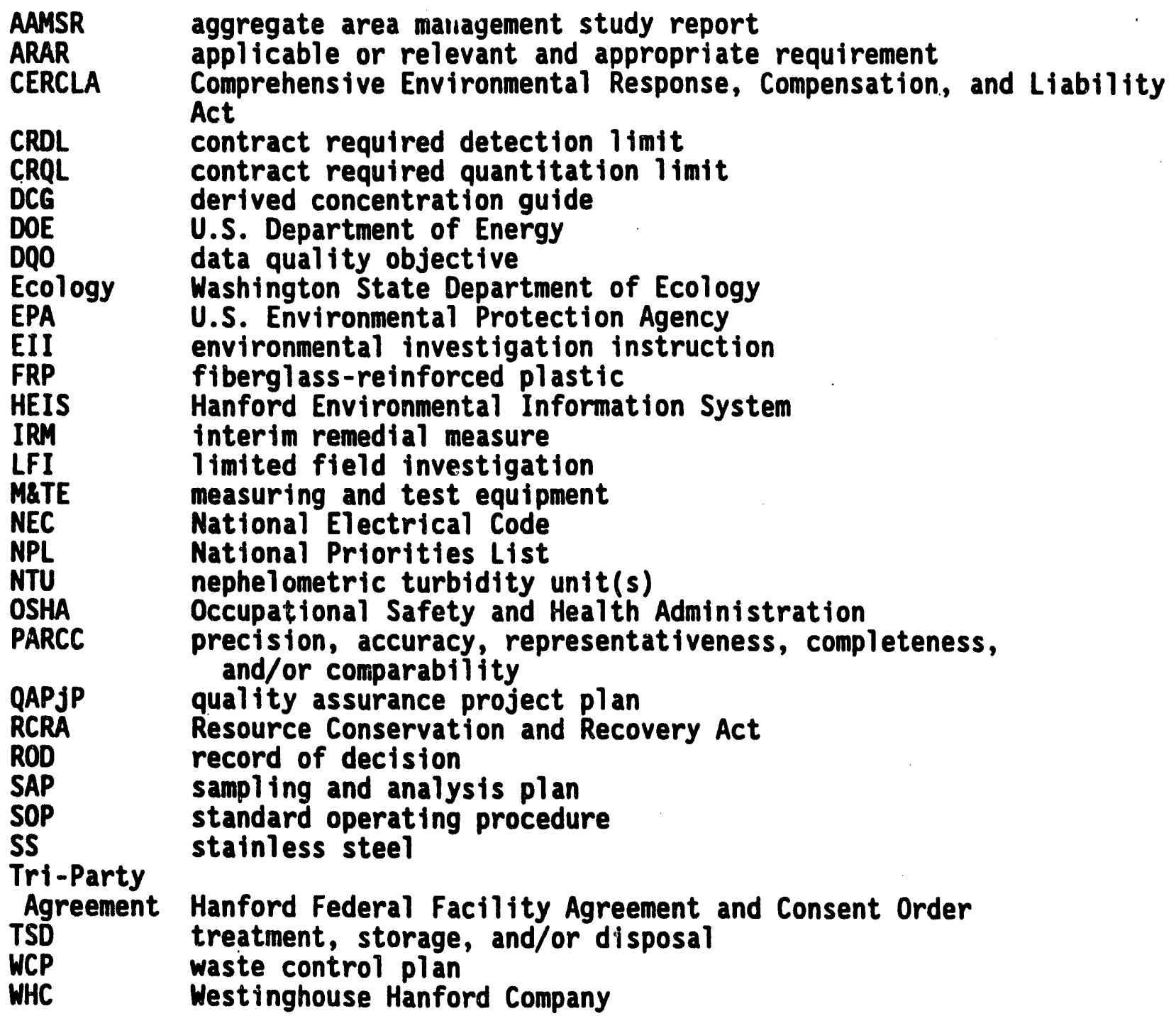


DOE/RL-93-105

Rev. 0

CONTENTS

1.0 INTRODUCTION . . . . . . . . . . . . . . . . . . 1-1

1.1 PURPOSE AND SCOPE ................. 1-3

1.2 SITE DESCRIPTION AND CONTAMINANTS . . . . . . . . . . . . . . . . . . $1-4$

1.3 GROUNDWATER CONCEPTUAL MODEL ................. 1 . . 1 . .

2.0 ALTERNATIVE DESCRIPTION AND TECHNOLOGY SELECTION . . . . . . . 2-1

2.1 PUMP AND TREAT ALTERNATIVE ................. 2- . . .

2.2 TREATMENT TECHNOLOGY ................. $2-2$

2.2.1 Treatment Technology Identification ....... 2-2

2.2.2 Treatment Technology Description ......... 2-3

3.0 TEST PERFORMANCE AND DATA QUALITY OBJECTIVES . . . . . . . . . 3-1

3.1 TEST PERFORMANCE OBJECTIVES ................ . . . $3-1$

3.2 DATA QUALITY OBJECTIVES ................. $3-2$

3.3 DATA INTERPRETATION .................. 3-3

3.4 ADDITIONAL DATA USES .................... $3-5$

4.0 TREATABILITY TEST DESIGN AND OPERATING REQUIREMENTS . . . . . . 4-1

4.1 LABORATORY TREATABILITY TESTING . . . . . . . . . . . . 4-1

4.2 PILOT-SCALE TREATABILITY TEST DESIGN . . . . . . . . . . . 4-2

4.2.1 Treatment Process Description .......... 4-2

4.2.2 Pilot-Plant Treatment Equipment ......... 4-. 4

4.2.3 Groundwater Withdrawal and Return .......... 4-4

4.2.4 Support Components ......... 4-. . . . .

4.3 TREATABILITY TEST SYSTEM OPERATION ............ 4-5

4.3.1 Fabrication and Setup ............. 4-5

4.3.2 Operation ................ 4-6

4.3.3 Process Waste Management ............. 4-7

4.3.4 Process Monitoring................ $4-7$

4.4 TEST WELL SELECTION ...................... $4-8$

4.5 GROUNDWATER MONITORING .................... 4 . . . . . .

4.5.1 Requirements ................ 4-10

4.5.2 Sampling and Analysis Pian ..................... 4-10

4.6 HEALTH AND SAFETY ................... 4-11

5.0 SUPPORTING DOCUMENTS . . . . . . . . . . . . . . . . 5-1

6.0 REPORTS ........................... 6-1

7.0 SCHEDULE . . . . . . . . . . . . . . . . . . . . . 7-1

8.0 PROGRAM ORGANIZATION . . . . . . . . . . . . . . . . . 8-1

9.0 REFERENCES . . . . . . . . . . . . . . . . . . . 9-1 
DOE/RL-93-105

Rev. 0

CONTENTS (Cont)

\section{FIGURES:}

1-1 Hanford Site Map ..................... 1F-1

1-2 Uranium Groundwater Plume Map for the 200-UP-1 Operable Unit . . IF-2

1-3 Technetium-99 Groundwater Plume Map for the 200-UP-1 Operable Unit ................... IF-3

1-4 200 West Area ....................... $1 F-4$

4-1 Legend for Conceptual Process Flow Diagram . . . . . . . . . . 4F-1

4-2 Conceptual Process Flow Diagram, 200-UP-1 Operable Unit Treatability Test .................... 4F-2

4-3 Proposed Site PIan for the 200-UP-1 Operable Unit

Treatability Test ................... 4F-3

7-1 Treatability Test Schedule . . . . . . . . . . . . . 7F-1

8-1 200-UP-1 Operable Unit Groundwater Treatability Test ..... . 8F-1

\section{TABLES:}

1-1 Summary of 200-UP-1 Operable Unit Conceptual Model Data . . . . 1T-1

3-1 Data Quality Objectives for Laboratory-Scale Testing of Ion Exchange Resins . . . . . . . . . . . 3T-1

3-2 Data Quality Objectives for 200-UP-1 Pilot-Scale Groundwater Treatability Test ........ . . 3T-2

4-1 Estimated Groundwater Production for the 200-UP-1 Well Useability Tests .................... 4T-1

4-2 Summary of Construction Information for Monitoring Welis in the Vicinity of the 200-UP-1 Operable Unit Treatability Test Site . 4T-2

4-3 List of Analytes for Groundwater Monitoring .......... 4T-3

\section{APPENDIXES:}

A 200-UP-1 Operable Unit Treatability Test Waste Control Plan . . A-1

B 200-UP-1 Operable Unit Treatability Test Process Sampling and Analysis Plan .................. B-1

\section{ATTACHMENT:}

1 Metric Conversion Chart 
DOE/RL-93-105

Rev. 0

\subsection{INTRODUCTION}

The 200 Areas of the Hanford Site (Figure 1-1) are included on the U.S. Environmental Protection Agency (EPA) National Priorities List (NPL) under the Comprehensive Environmental Response, Compensation, and Liability Act (CERCLA). The Hanford Site, established in 1943, was originally designed, built, and operated to produce plutonium for nuclear weapons using production reactors and chemical reprocessing plants. Operations in the 200 Areas involved mainly separation of special nuclear materials from irradiated nuclear fuels and related chemical and fuel processing and waste management. In general, chemical and low-level radioactive liquid wastes associated with these operations were typically disposed to the ground via infiltration structures such as cribs, ponds, ditches, and injection wells resulting in groundwater contamination.

An aggregate area management study program was implemented under the Hanford Federal Facility Agreement and Consent Order (Tri-Party Agreement) (Ecology et al. 1989a) to assess source and groundwater contamination in the 200 Areas. Based on the findings of the studies, an overall remedial action strategy for the 200 Areas was developed that favored the implementation of interim remedial actions to expedite the cleanup process. High priority groundwater contaminants were identified and interim remedial action recommendations were made following the Hanford Past-Practice Strategy (DOE-RL 1991). Recommendations were made based on the urgency for action and whether the nature and extent of the contamination was adequately understood to select and implement remedial actions.

The 200 West Groundwater Aggregate Area Management Study Report (AAMSR) (DOE-RL 1992a) summarized information about groundwater contaminants beneath the 200 West Area and provided recommendations for prioritizing, investigating, and remediating various contaminants and plumes. The 200 West Groundwater AAMSR (DOE-RL 1992a) recommended that three contaminants/plumes containing the highest concentrations of uranium, technetium-99 ( $99 \mathrm{TC})$, and nitrate be addressed under an interim remedial measure (IRM). Discussions between the U.S. Department of Energy (DOE), the EPA, and the Washington State Department of Ecology (Ecology) have resulted in an agreement in principle to address all three contaminants/plumes under one IRM. The three contaminants/ plumes are encompassed in the 200-UP-1 Operable Unit, and are hereinafter referred to as the IRM plume.

The 200 West Groundwater AAMSR (DOE-RL 1992a, Section 7.0) provided an initial feasibility study that screencd technologies for groundwater remediation in the 200 West Area and developed preliminary action alternatives. These alternatives include no action, institutional control, pump and treat, treatment at point of use/discharge, and physical or hydraulic containment/ control. Of these alternatives, pump and treat is considered to be an apprcpriate interim action alternative, considering the IRM goal of risk reduction. Pump and treat has been agreed on by DOE, EPA, and Ecology for pilot-scale testing at the 200-UP-1 Operable Unit as documented in the TriParty Agreement (Ecology et al. 1989a) Change Control Form M-13-93-03 (Ecology et a1. 1994). This agreement also requires the preparation of an IRM Proposed Plan following completion of the pilot-scale treatability test, and clarifies that the primary contaminants to be addressed in the 200-UP-1 Operable Unit. 
DOE/RL-93-105

Rev. 0

pilot-scale test are uranium and ${ }^{99} \mathrm{Tc}$. Although the pilot-scale treatment system will be specifically designed to remove these radionuclides, the system will also be assessed for its effectiveness in removing secondary contaminants (e.g., nitrate) known to exist in the ground-water. Treated groundwater will be returned to the aquifer within the boundary of the IRM plume from which it was withdrawn.

A work plan for the 200-UP-1 Operable Unit (DOE-RL 1993a) defines a limited field investigation (LFI), identifies the need for a pilot-scale pump and treat test, and discusses the IRM process. Following completion of the pilot-scale treatability test, an IRM Proposed PIan will be prepared to support an interim action record of decision (ROD). The IRM Proposed PIan will be supported by the results of the treatability test and other applicable operable unit activities (e.g., the LFI, a qualitative risk assessment). The IRM Proposed Plan will develop and evaluate a limited number of alternatives (e.g., pump and treat, hydraulic control, no action). The need for additional activities (e.g., treatability testing, field investigations) will be addressed in the IRM Proposed PI an and/or the interim action ROD. Once issued, the interim action ROD will address CERCLA standards, including satisfaction of federal and state applicable or relevant and appropriate requirements (ARARs), pertinent to implementing the required interim action. Any residual contamination not addressed in the interim action ROD should be addressed in the final remedy selection process.

Although pump and treat is generally considered to be a viable means of reducing the mass of mobile contaminants in groundwater, numerous sitespecific factors (e.g., aquifer heterogeneity) may influence the effectiveness and selection of pump and treat as an interim action alternative. The purpose of the treatability testing described in this test plan will be to assess the ability to meet test performance objectives, which include establishing effectiveness, operating parameters, and resource needs associated with extracting and treating the primary contaminants present in the IRM plume. The test will also serve as a proof-of-principle demonstration, and estabi ish engineering design values and functional costs to support the selection of an effective treatment technology. If treatability test results indicate that the pilot-scale system provides effective contaminant removal, it may be appropriate to continue operating the system, at its maximum or some other capacity, until an interim action ROD is developed. Any such decisions will al so be dependent on the results of related pump and treat investigations, and will be developed and documented jointly with the regulatory agencies through Unit Manager meetings, descriptions of work, and other formal means.

It may be determined during treatability testing that pumping groundwater would not efficiently achieve a significant amount of contaminant mass reduction in the groundwater, thus indicating that the goal of an IRM, risk reduction, may not be best achieved by a pump and treat interim action aiternative. Nevertheless, this treatability test plan anticipates the performance of treatment system testing for groundwater removed from the IRM plume even though it has not been determined whether pumping groundwater will effectively remove significant contaminant mass. The overali rationale for this approach is based on the following key reasons:

- Current evidence indicates that uranium, ${ }^{99} \mathrm{Tc}$, and nitrate are highly mobile within the IRM plume, so it is expected that 
contaminant mass removal will be sufficient for treatment system testing purposes.

- Data on treatment effectiveness will be needed to support the evaluation of potential treatment technologies.

- Treatment system test results will be usable for other Hanford Site (and/or other DOE facility) response alternative evaluations by providing effectiveness data on similar contaminants and media.

- Groundwater pumped to the surface to assess the ability to extract contaminants from the aquifer would be treated prior to return, which is consistent with a bias for action and the goal of risk reduction.

This treatability test plan is a secondary document, as this term is defined in the Tri-Party Agreement (Ecology et al. 1989a). Following the completion of pilot-scale testing, a treatability test report will be prepared summarizing the results of this study. Pilot-scale testing is expected to be completed in 1994.

\subsection{PURPOSE AND SCOPE}

Pilot-scale treatability testing has been identified as a principal activity required to support an interim action ROD for the 200-UP-1 Operable Unit by providing critical performance and cost information regarding groundwater treatment. The purpose of the pilot-scale treatability test is to demonstrate and gather data to optimize a preferred treatment system. Information on the system's treatment effectiveness, operating parameters, and resource needs will be collected to support the IRM alternative selection process for the IRM plume identified in the 200-UP-1 Operable Unit. Additional data, also in support of the IRM alternative selection process, will be gathered under separate activities (e.g., LFI). This treatability test plan focuses on assessing the performance of an aboveground treatment system with respect to the removal of uranium and ${ }^{9} \mathrm{TC}$ from extracted groundwater.

A 1 imited laboratory treatability test program will be implemented in support of the pilot-scale test. The laboratory program will evaluate the effectiveness of a number of different resins at removing uranium and ${ }^{99} \mathrm{TC}$ from 200-UP-1 Operable Unit groundwater samples. The results of the laboratory-scale testing will be used to identify a preferred resin for use in the pilot-scale test. In addition, the resins will be evaluated for their effectiveness at removing nitrates.

The scope of the test plan includes defining the following:

- preferred treatment technology to be tested

- test performance objectives and data quality objectives (DQOs)

- conceptual treatment system design

- specific tasks to finalize design and implement test 
DOE/RL-93-105

Rev. 0

- sampling and analysis procedures
- waste control and disposition
- quality assurance/quality control
test schedule.

\subsection{SITE DESCRIPTION AND CONTAMIMANTS}

In the 200 West Groundwater AAMSR (DOE-RL 1992a), recommendation of plumes for interim actions involved consideration of an initial risk-based screening as well as comparison of known contaminant concentrations in groundwater against pertinent federal and state groundwater standards. The initial risk-based screening performed in the 200 West Groundwater AAMSR (DOE-RL 1992a) was designed to prioritize contaminant plumes on a consistent semiquantitative basis for their relative intrinsic significance to human health. Overall, this risk-based screening was qualitative in nature and does not imply actual human health risks nor the existence of an exposure pathway. Uranium and $9 \mathrm{Tc}$ were ranked higher in priority on the basis of their relative health risk indices. In addition, uranium and ${ }^{\circ} \mathrm{TC}$ were recommended for interim actions because well-defined plumes were observed for which concentrations exceeded 1/25th (4\%) of the administratively established derived concentration guide (DCG) standards for groundwater (DOE Order 5400.5).

Based on the considerations outlined above, it was concluded that uranium may present high potential relative risk for both its noncarcinogenic and carcinogenic characteristics, and some groundwater samples have exceeded $4 \%$ of the DCG for uranium $(24 \mathrm{PCI} / \mathrm{L})$ by up to about 100 times. Technetium-99 may present high potential relative carcinogenic risk, and concentrations observed in some groundwater samples exceed $4 \%$ of the DCG for ${ }^{9}{ }^{T C}(4,000$ $\mathrm{PCi} / \mathrm{L}$ ) by over six times. Furthermore, the 200 West Groundwater AAMSR (DOE-RL 1992a) recommended that the IRM plume (i.e., the multicontaminant uranium, $9 \mathrm{Tc}$, nitrate plume) receive priority relative to other IRM contaminants in the 200 West Area due to a relatively high, combined potential carcinogenic and noncarcinogenic risk.

Contaminant concentration information is maintained in the Hanford Environmental Information System (HEIS) database (DOE-RL 1994). This information and computer contouring software form the basis for the plume maps presented in Figures 1-2 and 1-3. The data and software have inherent limitations on their ability to extrapolate boundaries. As shown on Figures 1-2 and 1-3, the uranium and ${ }^{9} \mathrm{TC}$ plumes are generally colocated in the area underlying the $U$ Plant Complex, the 216-U-1 and 216-U-2 Cribs, the 216-U-8 Crib and the 216-U-17 Crib. The pilot-scale test will be conducted in the vicinity of the 216-U-17 Crib (Figure 1-4), which is situated in the southeast quadrant of the plumes. Except for the 216-U-17 $\mathrm{Crib}$, the surface area for the test site is open and has good access.

In general, the highest observed uranium concentration, at 2,258 parts per billion (ppb), occurs east of the 216-U-1 and 216-U-2 Cribs, with concentrations around the 216-U-17 Crib occurring in the range of approximately 150 to $900 \mathrm{ppb}$. Technetium-99 concentrations are highest in the area of the 216-U-17 Crib, with reported concentrations in the range of approximately 3,000 to $22,900 \mathrm{pCi} / \mathrm{L}$. Concentrations observed for nitrate also are highest in the area of the 216-U-17 Crib, with detections in the range of 
approximately 400 to $1,300 \mathrm{mg} / \mathrm{L}$. Other contaminants with well defined plumes that are observed within the target area of the IRM plume include: carbon tetrachloride, chloroform, iodine-129 ( $\left.{ }^{129} \mathrm{I}\right)$, arsenic, and fluoride.

\subsection{GROUNDWATER CONCEPTUAL MODEL}

The groundwater conceptual model presented for the 200-UP-1 Operable Unit pilot-scale treatability test site includes information about contaminant sources, disposal practices, release mechanisms, affected media, exposure routes of receptors, and aquifer characteristics. The conceptual model was developed from data and information obtained from the $U$ Plant AAMSR (DOE-RL $1992 b$ ), the 200 West Groundwater AAMSR (DOE-RL 1992a), the Remedial Investigation/Feasibility Study Work Plan for the 200-UP-1 Groundwater Operable Unit, Hanford Site, Richland, Washington (DOE-RL 1993a), the Remedial Investigation/Feasibility Study Work Plan for the 200-UP-2 Source Operable Unit, Hanford Site, Richland, Washington (DOE-RL 1993b), the Hydrogeologic Model for 200 West Aggregate Area (Connelly et al. 1992), the Unconfined Aquifer Hydrologic Test Data Package for the 200 Areas Groundwater Aggregate Area Management Study (Newcomer et al. 1992), and the Groundwater Maps of the Hanford Site, December 1992 (Kasza et al. 1993). Aquifer properties and contaminant distribution will continue to be characterized and evaluated through the LFI activities that are being conducted in parallel with the pilot-scale test (DOE-RL 1993a).

The $U$ Plant complex (Figure 1-4), which includes the 221-U and 224-U Buildings, was constructed in 1944 to support plutonium production during World War II (DOE-RL 1992b) and was used in a training role until 1952, when it was converted to uranium recovery operations. The 221- $U$ Building was placed on standby in 1958 and has since been used to store contaminated equipment. Additional uranium reduction took place in the 224-U Building in support of the plutonium-uranium extraction process from 1952 unt il final uranium stabilization activities in 1994. Liquid rastes from the $U$ Plant complex were disposed of to tank farms, eight cribs, and five french drains, as well as the $U$ Pond complex.

The 216-U-1 and 216-U-2 Cribs are 12 by 12 by $4 \mathrm{ft}$ deep wooden structures buried $20 \mathrm{ft}$ deep in native soil and were in operation from 1957 to 1967 (DOE-RL 1992b). It is estimated the cribs received a total of 12,206,100 gal (DOE-RL 1993a) of liquid waste, including $0.7 \mathrm{Ci}$ of uranium and $42.6 \mathrm{~g}$ of plutonium (DOE-RL 1992b) as well as 2,640,000 lb of nitrate. As described in the U Plant AAMSR (DOE-RL 1992b), the 216-U-8 Crib is a 160- by 50- by $40-\mathrm{ft}$ deep crib that is estimated to have received 100,000 gal of acidic process condensate and stack drainage, including 91,000 ib of nitric acid, from 1952 to 1960 . The $216-\mathrm{U}-8 \mathrm{Crib}$ is est imated to have received $40,000,000 \mathrm{gal}$ of liquid waste containing plutonium and uranium (DOE-RL 1992b).

The 216-U-12 Crib is an active Resource Conservation and Recovery Act (RCRA) treatment, storage, and/or disposal (TSD) facility constructed in 1960 when the 216-U-8 Crib started to subside (DOE-RL 1992b). The crib is approximately 150 by 10 by $7 \mathrm{ft}$ deep and has no internal structures. The 216-U-12 Crib received an estimated $40,000,000 \mathrm{gal}$ of waste from a variety of sources including U Plant stack drainage, 224-U Building acidic process condensate, storm drain wastes and drainage from the 241-WR Thorium Storage Vault. The. 
crib received uranium and minor quantities of other radionuclides. No chemical inventory is given (DOE-RL 1992b).

The 216-U-16 Crib is a 62- by 191- by 15-ft deep gravel filled drain field (DOE-RL 1992b). In 1984, the 216-U-16 Crib was installed south of the 216-U-1 and 216-U-2 Cribs. This crib received approximately 108,046,000 gal of cooling water (DOE-RL 1992b). The 216-U-17 Crib was constructed in 1988 to replace the 216-U-12 Crib (DOE-RL 1992b). It is currently on standby and receives only 224-U Building process condensate. The crib is thought to have received small quantities of plutonium, americium, and uranium (DOE-RL 1992b).

Nitrate discharged to the 216-U-1 and 216-U-2 Cribs probably combined with uranium in the vadose zone and formed soluble compounds (Delegard et al. 1986). By 1985, the volume of cooling water discharged to the 216-U-16 Crib was sufficient to form a perched water layer that migrated beneath the 216-U-1 and 216-U-2 Cribs and mobilized the soluble uranium. The uranium probably migrated through the plio-pleistocene "caliche" layer through fissures and along well casings at the cribs to groundwater (DOE-RL 1993a). Concentrations at monitoring wells in the vicinity of the 216-U-1 and 216-U-2 Cribs increased from 166 to 72,000 pCi/L. Between June. and August of 1985, approximately $7,900,000$ gal of groundwater were treated through ion exchange columns and approximately 1,500 1b of uranium were recovered (DOE-RL 1992b, Delegard et a). 1986).

The uranium plume has an area of approximately $4,949,600 \mathrm{ft}^{2}$ (Figure 12) and an estimated mass of 583.2 ib of uranium. The ${ }^{\circ}$ Tc plume has an area of approximately 8,070,000 $\mathrm{ft}^{2}$ (Figure 1-3) and an estimated mass of $.7,1 \mathrm{~b}$ of 9. Tc. The nitrate plume covers an area of approximately $129,120,000 \mathrm{ft}^{2}$ and contains approximately 7,040,000 lb of nitrate (DOE-RL 1992a). Estimates of primary contaminant mass in the plumes are presented in Table 1-1. The estimates for contaminant mass in the plumes are based on computer generated contours of groundwater sampling data and an assumed plume thickness of $33 \mathrm{ft}$. As discussed in the 200 West ground-water AAMSR (DOE-RL 1992a, Section 4.0), although contaminants have migrated from the source area, they are not directiy exposed to the surface environ-ment. There are no known existing release exposure pathways and, currentiy, no known human or environmental receptors associated with the IRM plume.

The IRM plume in the vicinity of the test site is in the unconfined aquifer contained within the Ringold Formation Unit $E$. The Ringold Unit $E$ gravels are locally heterogeneous and consist of clast supported granule to cobble gravel with a sandy matrix and intercalated lenticular beds of sand and silt that can range from <1 in. to many feet in thickness (DOE-RL 1992a). Depth to groundwater at the test location is approximately $240 \mathrm{ft}$ below land surface. The aquifer in which the contaminant plumes are located is under unconfined hydraulic conditions and has a saturated thickness of approximately $160 \mathrm{ft}$. Horizontal groundwater flow directions are oriented to the east and east-southeast with a gradient of 0.0016 to 0.002 (Kasza et al. 1993). Connelly et al. (1992) give aquifer transmissivities based on aquifer test data of approximately 1,000 to $5,000 \mathrm{ft}^{2} / \mathrm{day}^{2}$ and conductivities of 6 to $35 \mathrm{ft} /$ day. 
Soil-water distribution coefficients for uranium, ${ }^{90} \mathrm{TC}$, and nitrate are all relatively low (Table 1-1). The U Plant AAMSR (DOE-RL 1992b) gives distribution coefficient $\left(K_{f}\right)$ values of 0 for nitrate and 0 to 1 for ${ }^{90} \mathrm{TC}$, indicating little or no tendency to sorb to Hanford Site soils. Uranium also has a $K_{d}$ value of 0 to 3 , and in addition is likely to be complexed with nitrate in the vicinity of the 216-U-1 and 216-U-2 Cribs, further increasing solubility (DOE-RL 1993a).

Available data suggest that there is little tendency for the primary contaminants in the IRM plume to sorb to the fine-grained fraction of the Ringold Formation (DOE-RL 1992a). Dissolved uranium is expected to exist as a neutral hydroxide species (at a neutral $\mathrm{pH}$ ) and, thereby, will sorb very poorly and have moderate mobility. Technetium-99 typically forms negative ions in oxidizing environments and does not readily complex with other chemical species. Consequently, there is little opportunity for ${ }^{99}$ Tc to sorb, which results in a fairly mobile radionuclide. Nitrate exists as a negative ion and is highly soluble in water.

Based on the above geochemical information and current aquifer data, it is likely that uranium, "Tc, and nitrate are relatively mobile in saturated zone soils. These conclusions, in conjunction with the likelihood of high aquifer conductivity, support a high probability that pumping the IRM plume groundwater can resuit in the removal of a significant contaminant mass. This treatability test plan discusses monitoring and other activities that will be conducted during the pilot-scale pump and treat test; treatability test results, along with other 200-UP-1 Operable Unit investigations (e.g., the LFI), will be used to help validate this expectation. 


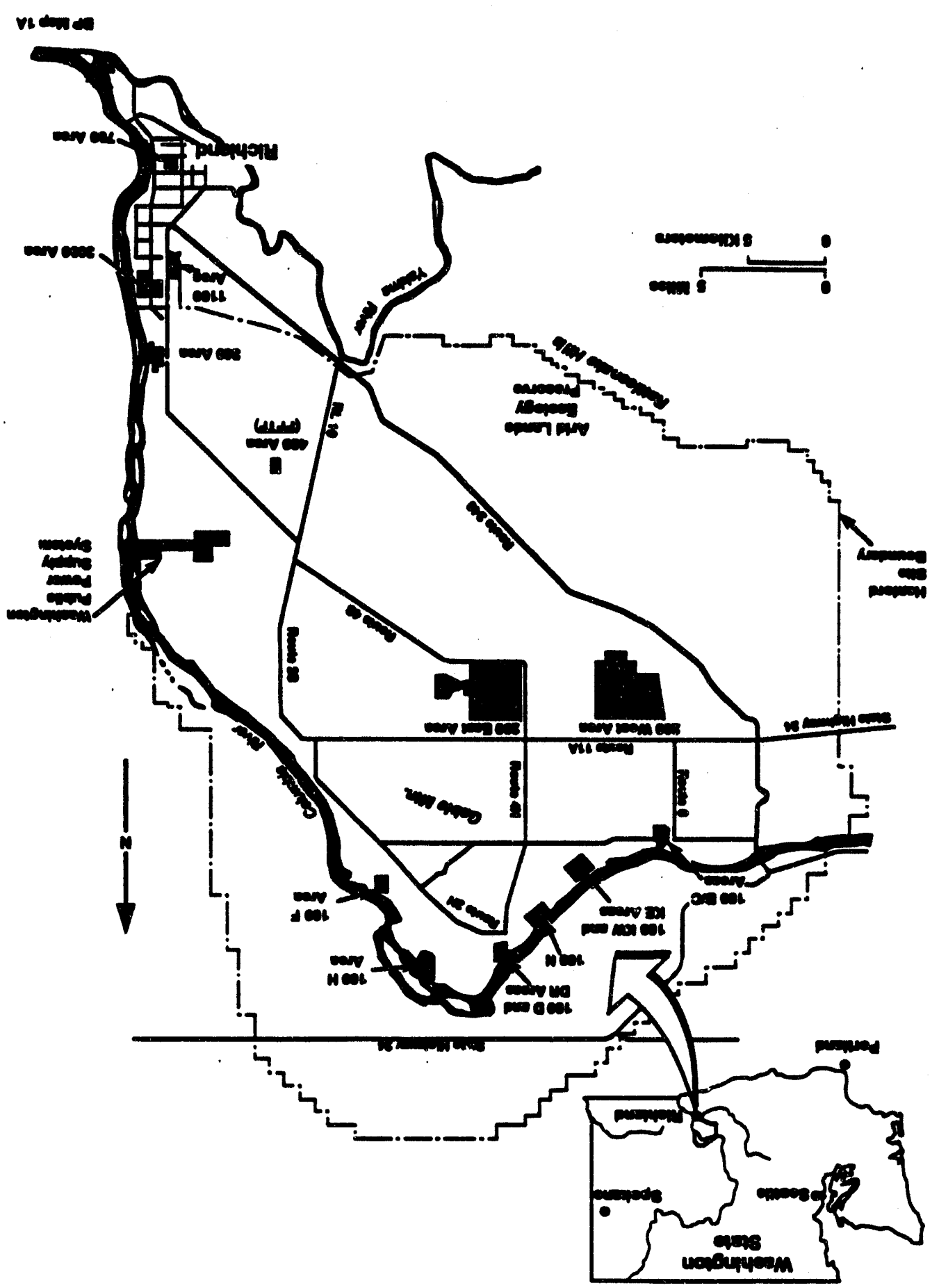

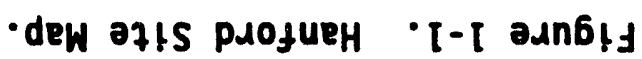




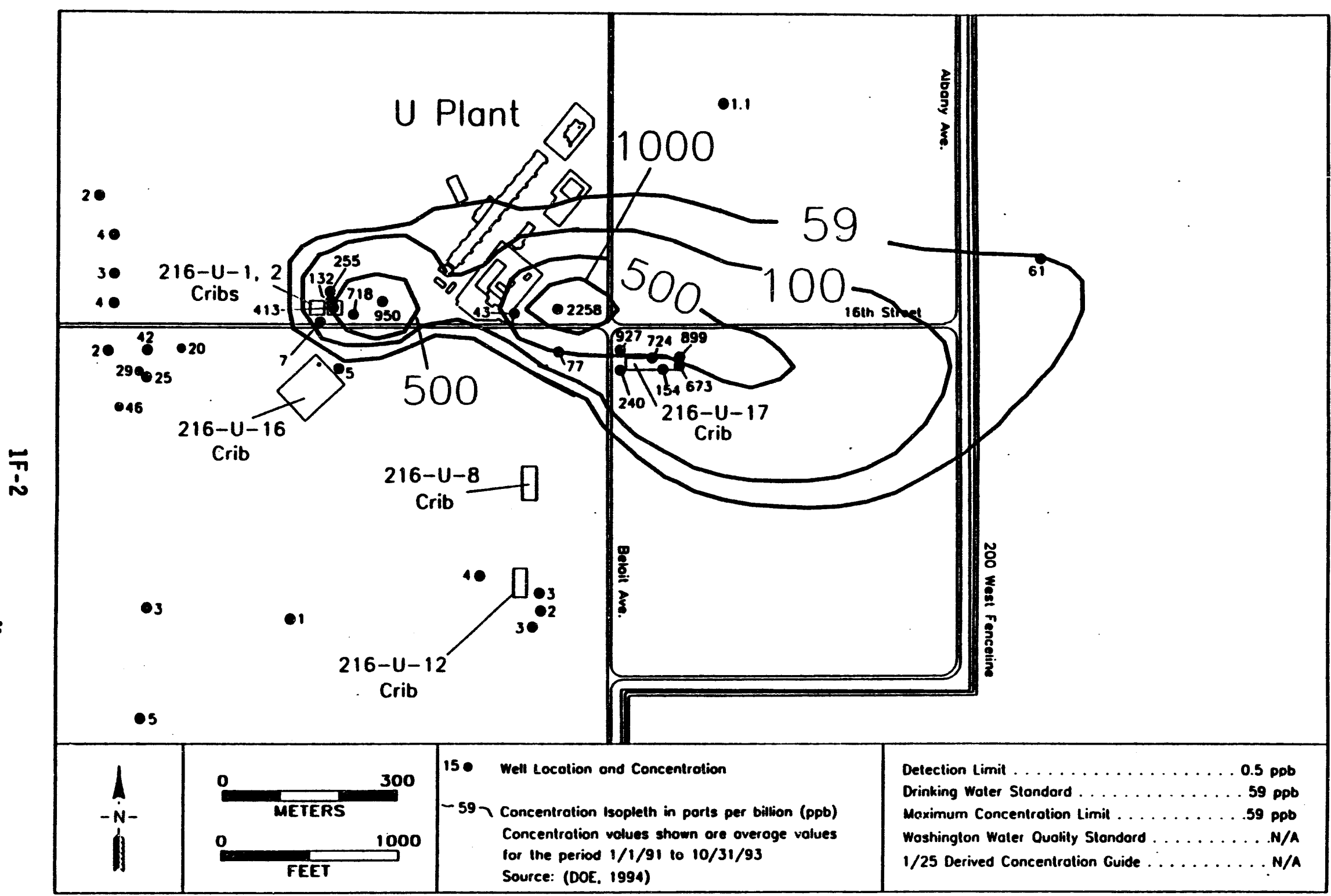

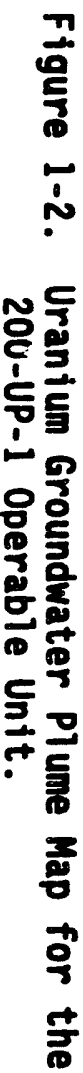

WHC GEOHYDRO 021794 


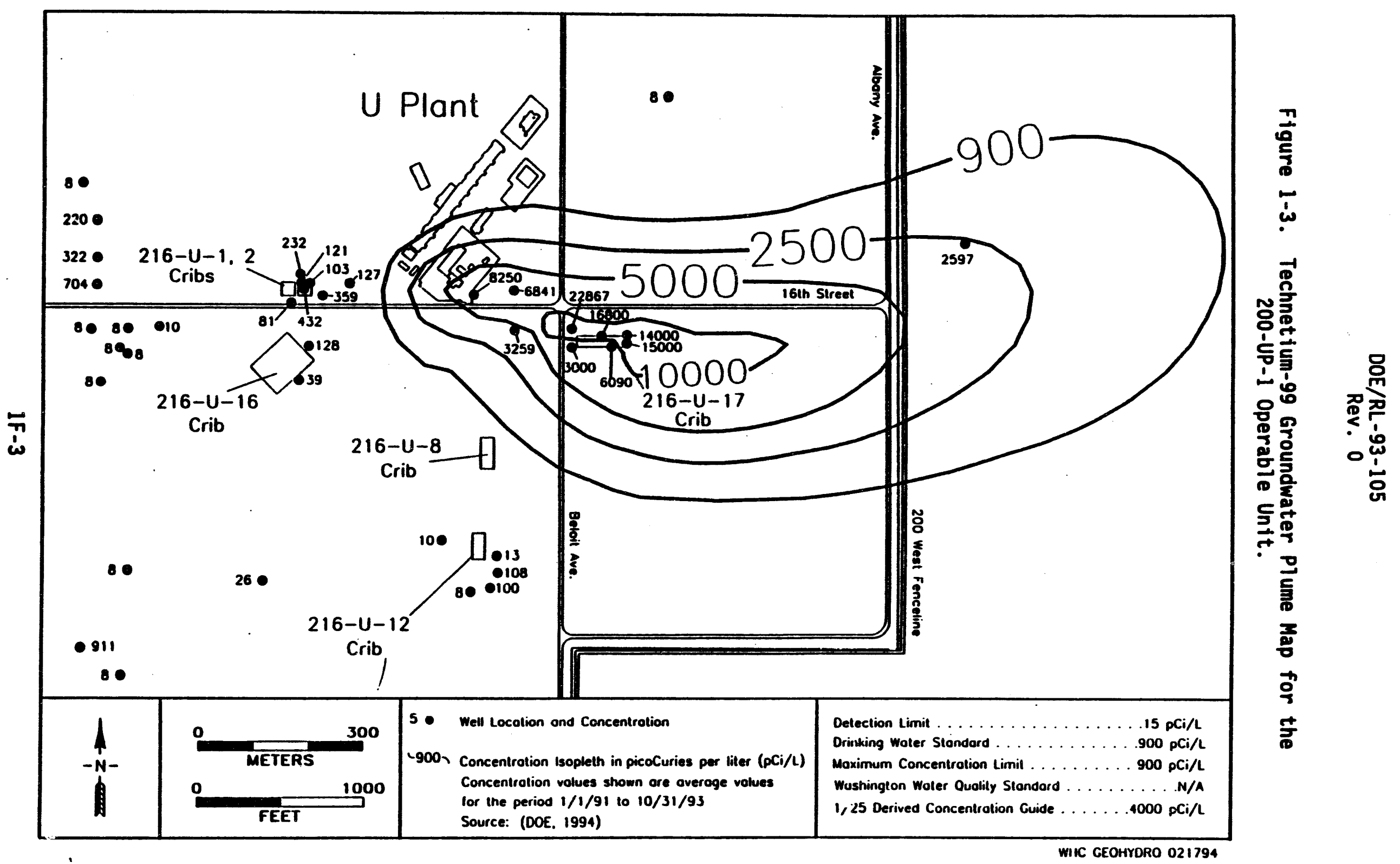


DOE/RL-93-105

Rev. 0

Figure 1-4. 200 West Area.

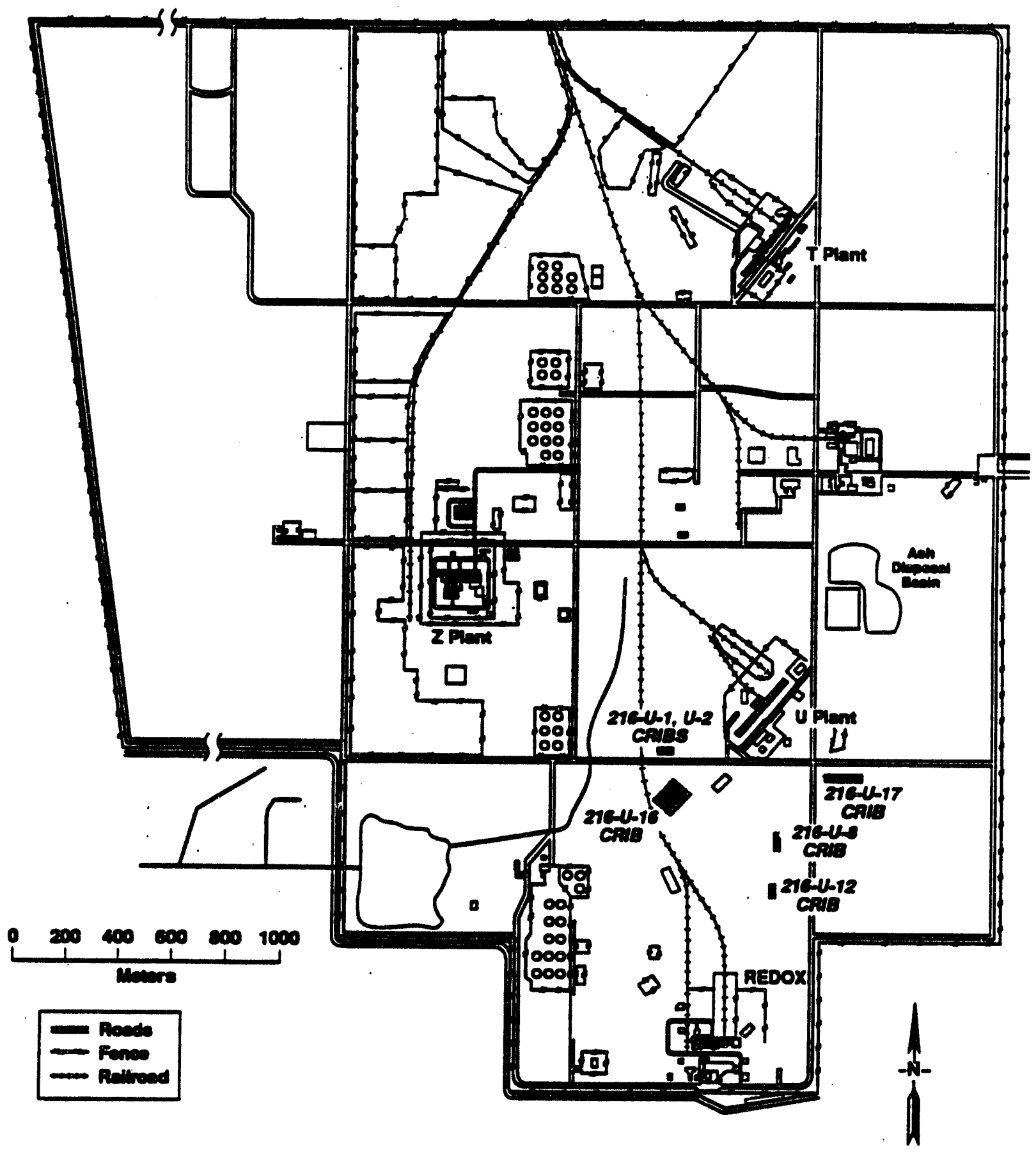

200 MBET NAEA 


\begin{tabular}{|c|c|c|c|c|c|c|c|}
\hline $\begin{array}{c}\text { Contami- } \\
\text { nant }\end{array}$ & $\begin{array}{c}\text { Quantity } \\
\text { Disposed to } \\
\text { the } 216-U-1 \\
\text { and } 216-U-2 \\
\text { Cribs" }\end{array}$ & $\begin{array}{l}\text { Dissolved } \\
\text { Plume } \\
\text { Contaminant } \\
\text { Mass }\end{array}$ & $\begin{array}{l}\text { Half } \\
\text { Life }^{b}\end{array}$ & $\begin{array}{c}\text { Maximum } \\
\text { Average } \\
\text { Concentration } \\
\text { (Wel1) }^{c}\end{array}$ & $\begin{array}{l}\text { Mobili } \\
\text { ty } \\
\left(K_{f}^{\text {in }}\right. \\
\mathrm{mL} / g)^{b}\end{array}$ & $\begin{array}{c}\text { Specific } \\
\text { Activity } \\
(\mathrm{C} 1 / \mathrm{g})\end{array}$ & $\begin{array}{l}\text { Primary } \\
\text { Decay } \\
\text { Mode }\end{array}$ \\
\hline Uranium & $\begin{array}{l}0.7 \mathrm{Cj}^{b} \\
(2268 \mathrm{lb})\end{array}$ & $\begin{array}{l}0.18 C^{d} \\
(583.21 b)\end{array}$ & $\begin{array}{l}4.5 \times \\
10^{9} \times \\
\text { years }\end{array}$ & $\begin{array}{l}2,257.4 \quad C .1 / L \\
\left(299-w_{1} g-18\right)\end{array}$ & $\begin{array}{l}\text { High } \\
(0-3)\end{array}$ & ${ }_{10^{-7}}^{6.79} \times$ & Alpha \\
\hline${ }^{99} \mathrm{TC}$ & Unknown & $\begin{array}{l}5.6 \mathrm{Ci}^{\mathrm{d}} \\
(.7 \mathrm{lb})\end{array}$ & $\begin{array}{l}213,000 \\
\text { years }\end{array}$ & $\begin{array}{l}28,262.5 \\
\mathrm{pCi} / L \\
(299-U 19-24)\end{array}$ & $\begin{array}{l}\text { High } \\
(0-1)\end{array}$ & ${ }_{10^{-2}}^{1.79} x$ & Beta \\
\hline
\end{tabular}

- U Plent source MunsR (DOE-RL 1992b).

- 200 Hest Grounchater anuss (DOE-RL 1992a).

- R1/Fs work plen for the 200-UP-2 Opercble Unit (DOE-RL 1993b).

- oissolved plume mass is derived from estimtes of plume aree depicted in figures 1-2 and 1-3 (bosed on the outer plume boundary defined by the drinking unter stendard, such $28900 \mathrm{pCi} / \mathrm{L}$ for $\left.{ }^{0} \mathrm{TC}\right)$, an assumed $30 \mathrm{ft}$ plume thickness, and an

essumed porosity of 0.2 . Plume quentity estimtes will be revised by charecterization activities described in the RI/FS work plen for the 200-Up-1 Operable Unit (DOE-RL 1993a).

- For ureniun-238. 
DOE/RL-93-105

Rev. 0

\subsection{ALTERMATIVE DESCRIPTION AND TECHNOLOGY SELECTION}

A change described in the Tri-Party Agreement (Ecology et al. 1989a) Change Control Form M-13-93-03 (Ecology et al. 1994) requires that the DOE begin pilot-scale pump and treat uperations after March 31, 1994 in the 200UP-1 Operable Unit. This treatability test plan outlines a pilot-scale pump and treat system.

\subsection{PUMP AND TREAT ALTERNATIVE}

Pump and treat involves the withdrawal of contaminated groundwater, treatment aboveground using appropriate pretreatment and treatment technologies (e.g., filtration, ion exchange, etc.), disposition of secondary waste streams, and disposition of treated groundwater usually by return to the aquifer. The pump and treat alternative has an added benefit in that the extraction of groundwater, as well as the selective return of treated groundwater, can be used to hydraulically control plume expansion. Pump and treat system effectiveness depends on a variety of factors, including aquifer properties, contaminant characteristics, and treatment system operating parameters. Treatment technologies have been shown to be effective at treating groundwater in which contaminants are relatively concentrated and mobile. For example, a previous groundwater remediation effort in the vicinity of $U$ Plant demonstrated that ion exchange pump and treat can effectively remove uranium at high concentration from the groundwater (Delegard et al. 1986). However, treatment technologies become less cost effective as primary contaminant concentrations decline. In these cases, greater volumes of groundwater must be circulated through the system to remove an equivalent contaminant mass.

As discussed in the 200 West Groundwater AAMSR (DOE-RL 1992a, Section 9), an IRM should not be undertaken to specifically meet cleanup 1 imits or federal or state ARARs (e.g., maximum contaminant levels), but should be based on risk reduction. Under the IRM, the selected groundwater interim action should proceed until the response objective (e.g., reduction in risk) is met, a point of diminishing returns is reached, or natural attenuation exceeds active treatment. The IRM should be discontinued if one of these conditions is met, and any residual contamination should be addressed in the final remedy selection process.

A pump and treat treatability test program should include an assessment of potential limitations of the aquifer/contaminant system on the success of pump and treat as an interim action alternative. These limitations generaliy fall into two categories: hydraulic, which affect the ability to withdraw contaminated groundwater from the aquifer at an effective pumping rate; and physical/chemical, which affect the ability of pumped groundwater to carry primary contaminants with it, thereby facilitating extraction of the contaminants from the aquifer. The conceptual model of the 200-UP-1 IRM plume (Section 1.3) discussed the groundwater conditions and aquifer properties expected for the aquifer/contaminant systems. Based on anticipated aquifer conditions (relatively high transmissivities) and the relatively high mobility

of uranium, ${ }^{90} \mathrm{Tc}$, and nitrate, it is anticipated that pumping will extract significant quantities of primary contaminants. Groundwater primainy contam- 
DOE/RL $-93-105$

Rev. 0

inant concentrations will be monitored as an activity covered by the process sampling and analysis plan (SAP) and the groundwater monitoring SAP. This information, along with data from other ongoing activities at the 200-UP-1 Operable Unit, will be used to confirm effective removal of primary contaminants.

\subsection{TREATMENT TECHNOLOGY}

Ion exchange will be implemented as the treatment technology for the IRM plume in the 200-UP-1 Operable Unit pilot-scale groundwater treatability test. Ion exchange is a unit process that removes dissolved radioactive and nonradioactive ions (e.g., uranium and ${ }^{90} \mathrm{TC}$ ) from an aqueous solution (e.g., groundwater) by exchanging the ions with complementary fons attached to sites on the surface of an insoluble support material (typically, beads of synthetic organic resin). In cation resins (designed to remove positively charged ions), the exchange sites usually contain hydrogen ions, but they may also contain sodium or ammonium ions. In anion resins (designed to remove negatively charged ions), the exchange sites usually contain hydroxide ions, but other ions such as chloride can be used. Contact between the ion exchange resin and 200-UP-1 Operable Unit groundwater will be achieved by passing the groundwater through vessels filled with resin.

The fon exchange resin(s) that will be used for this treatability test will be selected for their ability to preferentially adsorb uranium and 9 Tc. Removal of secondary contaminants (principally nitrate) prior to treatment of the primary contaminants is not part of the treatability testing because the relatively high concentration of nitrates would result in a very short resin life and would require disposal of large quantities of spent resin. Most likely, a treatment process other than ion exchange would be selected if nitrate removal was the primary treatment goal.

\subsubsection{Treatment Technology Identification}

The primar; reason for identifying ion exchange is that the technical literature, test and operating experience, and professional judgement indicate it will be effective in treating primary contaminants in the IRM plume. The EPA evaluations of treatment at radioactively contaminated Superfund sites (EPA 1990), previous treatability studies at the Hanford Site (Delegard et al. 1986; Barney et a1. 1992), operating experience at the Oak Ridge National Laboratory (Robinson 1990), and numerous municipal and industrial water treatment applications (Baker et al. 1988; Sorg 1989, 1991; Jelinek and Sorg 1988; and Del Cul et al. 1992) have shown that fon exchange is a mature and effective technology for selectively removing radionuclides from both wastewater and groundwater. Although the concentrations of contaminants were generally higher and the concentrations of potentially interfering constituents were generally lower in these applications compared with those measured in the IRM plume, the results indicate that ion exchange will be effective in removing the uranium and ${ }^{\circ} \mathrm{Tc}$ contained in groundwater withdrawn from the IRM plume. 
DOE/RL $-93-105$

Rev. 0

If larger-scale operation is required in a future treatment system, the scaleup parameters for ion exchange systems are well defined. Ion exchange systems have been used to treat aqueous streams with large flow rates. Thus, if it is decided to further develop ion exchange as a potential interim action alternative, scaleup to support detailed evaluation and/or design of a fullscale system will be a straightforward process.

In ion exchange, contaminants are adsorbed and, thus, immobilized on the surface of the solid resin. In applications such as this treatability test, where "spent" resin (i.e., resin that has reached its practical adsorption capacity) is removed from the system for disposal, contaminants leave the system fixed in a stable secondary waste matrix that will resist leaching and minimize risk irom transportation mishaps, thus minimizing the possibility of future contamination or recontamination of the environment. Additionaliy, final waste handiing and disposal are straightforward operations. After spent resin is transferred from the vessel and dewaiered, it is expected to meet low-level waste acceptance criteria for long-term storage and/or final disposal. Facilities and expertise exist for transferring, dewatering, packaging, storing, and disposing of spent resin.

The mechanical simplicity of ion exchange technology combined with the ready availability of design expertise and standard equipment support expeditious design, construction, and operation of a pilot-scale ion exchange treatment system for the IRM plume. Rapid deployment will be consistent with achieving early risk reduction, thus furthering the primary goal of the IRM. The project plan is to construct skid-mounted systems that can be easily adapted to changes in test site locations, groundwater conditions (e.g., flow rates, contaminant concentrations), or treatability test DQO. The treatment system may also be used as a platform to test additional innovative treatment technologies.

\subsubsection{Treatment Technology Description}

The fon exchange resin(s) will have a finite adsorption capacity for the primary contaminants, related to the number of available ion exchange sites. A distinct advantage of lon exchange is that resin manufacturers have produced a wide variety of resins that can be very selective for targeted ion(s). However, uranium and ${ }^{9} \mathrm{TC}$ may have to compete for these exchange sites with secondary contaminants (e.g., nitrate) or other constituents found in groundwater. Because the concentrations of the primary contaminants are several orders of magnitude less than those of other groundwater constituents (e.g., nitrates, sulfates) in this treatability test, competing ionic species may determine resin exhaustion rates.

When the resin is spent, breakthrough will occur. Breakthrough is the point in the resin loading cycle when the concentration of uranium or $9 \mathrm{TC}$ rises to a predetermined concentration in effluent from the resin bed. In designing an ion exchange system it is important to select resins which optimize adsorption of the primary contaminants and maximize the time to breakthrough. For this treatability test, these resin selection objectives will be accomplished through laboratory. 
Typically, an ion exchange treatment system includes one or more pretreatment units to condition the stream for optimum performance in the ion exchange unit. The pilot-scale treatment system to be implemented at the IRM plume will include filtration and $\mathrm{pH}$ adjustment units for pretreatment.

A filtration unit will be incorporated as a pretreatment technology to remove suspended solids contained in the groundwater before it enters the leading ion exchange bed. This pretreatment will minimize the potential for any inert and/or biologically active suspended solids to accumulate on the resin surface, masking the exchange sites, and resulting in loss of exchange efficiency. It will also minimize the potential for solids to plug the void spaces among the beads of resin and restrict flow through the bed. Furthermore, because $r$ iny of the constituents in Hanford Site groundwater have an affinity for the soil, there is the potential for removing contamination associated with suspended solids, including radionuclides.

Experience indicates that the $\mathrm{pH}$ of the aqueous stream can affect selectivity of a given ion exchange resin for a given ion. Thus, a pH adjustment system will be included as a pretreatment process in the treatment system to support optimization of stream $\mathrm{pH}$. The $\mathrm{pH}$ adjustment system will include means for adding sodium hydroxide to increase $\mathrm{pH}$ (or hydrochloric acid to reduce it) before the stream enters the fon exchange vessels and to neutralize the $\mathrm{pH}$ (hydrochloric acid or sodium hydroxide) before the stream is returned to the aquifer.

A second filtration unit will be incorporated downstream of the fon exchange vessels to remove any suspended solids that may be formed by biological activity in the system, oxidation of dissolved spectes by exposure to the atmosphere, and/or by the addition of chemicals for $\mathrm{pH}$ adjustment. This downstream filtration will minimize any potential for plugging the return well. 
DOE/RL-93-105

Rev. 0

\subsection{TEST PERFoRMANCE AND DATA QUALITY OBJECTIVES}

Test performance objectives and DQOS are used to clarify and guide the testing process and to ensure that the quality and quantity of data are sufficient to support remedy selection decisions. Test performance objectives identify information neads required to evaluate a remedy. The DQOs 1 ink the information requirements with the intended data use to define the level of quality required for the measured variables. Data quality needs are defined by specifying precision, accuracy, representativeness, completeness, and/or comparability (PARCC) requirements.

The overall question that this treatability test plan seeks to answer, and that consequently affects the test performance objectives and DQOS presented in this section, is whether the treatment technology identified in Section 2.0 can effectively reduce concentrations of uranium and $9 \mathrm{Tc}$ in groundwater pumped from the IRM plume. This treatability test plan describes a number of test and development steps, including laboratory tests and pilotscale treatment tescing, intended to answer this question. The following sections describe the test performance objectives and DQOS for the treatability test program. For clarity, separate DQOs have been developed for the laboratory- and pilot-scale tests to facilitate development of detailed design, operating procedures, and monitoring activities.

\subsection{TEST PERFORMANCE OBJECTIVES}

The primary test performance objective for the pilot-scale treatment system is to determine the removal efficiency that can be achieved for the primary contaminants uranium and 90 Tc in groundwater pumped from the IRM plume. Test performance objectives are divided into three categories: measurement of the effectiveness of ion exchange treatment; assessment of parameters or factors influencing the ion exchange operation; and determination of the resource needs associated with the test. Specific objectives under each of the three categories include the following:

- Effectiveness

- Identify optimum/preferred ion exchange $\operatorname{resin}(s)$ for removing uranium and ${ }^{9} \mathrm{TC}$.

- Determine the effectiveness of the ion exchange system to consistently remove uranium and ${ }^{99} \mathrm{TC}$ from groundwater at a scale that is representative of a full-scale treatment process and under site-specific conditions. Based on previous Hanford experience and general expectations for ion exchange technology, and consistent with the Guide for Conducting Treatability Studies under CERCLA (EPA 1992), removal effectiveness should be at least 90\%.

- Assess the effectiveness of the ion exchange system in removing secondary contaminants (e.g., nitrate).

- Assess the impacts of secondary contaminants (e.g., nitrate) on treatment efficiency. 
DOE/RL - $93-105$

Rev. 0

- Operating Parameters

- Refine operational requirements/procedures.

- Identify and assess impacts of groundwater constituents (e.g., calcium carbonate, chloride, nitrate, phosphate, sulfate) on operational efficiency.

- Assess operating parameters (e.g., flow rates, residence times, pH) to optimize treatment efficiency.

- Demonstrate operational reliability and safety of an ionexchange system at a scale sufficient to allow confident scale-up to a full-scale remedial system.

- Resource Requirements

- Develop estimates of significant cost components, inciuding equipment and material costs; mobilization and demobilization costs; resin contaminant exchange capacity, exhaustion rate, and cost; electrical power and utility costs; chemical costs and use rates; process residue and secondary waste management costs; maintenance requirements; monitoring, sampling, and analysis costs; and operator and personnel requirements.

- Refine health and safety requirements.

The treatability test program is designed to meet these performance objectives through the following test steps, including:

- Laboratory testing of resins using site-specific groundwater samples to select the preferred resin(s) for use in the pilotscale treatability test.

- Pilot-scale testing of an ion exchange based treatment system.

\subsection{DATA QUALITY OBJECTIVES}

According to the EPA document Data Quality Objectives for Remedial Response Activities--Development Process (EPA 1987) and as developed in the 200 West Groundwater AAMSR (DOE-RL 1992a), DQOs are qualitative and quantitative statements that specify the quality of data required to support remedial action decisions and are determined based on the end uses of the data to be collected. The end use of the treatability study data is to support the alternative evaluation process in the IRM Proposed Plan. Expected users of the test data include:

- DOE, EPA, and Ecology remedial project managers

- DOE, EPA, and Ecology unit managers

- Westinghouse Hanford Company (WHC) remedial investigation coordinators. 
To ensure that data collected are of sufficient quality to evaluate the ion exchange treatment system, appropriate $\mathrm{DQOS}$ were developed. The importance and ramifications of the remedial decisions that will be made and supported using the treatability test data formed the basis for defining these DQOS. Because the data will be used to support the remedy selection process for an interim action, DQOs were defined that are less rigorous than those required to support final remedial decisions or remedial designs. Data to assess treatment effectiveness and costs are considered critical to meeting the test objectives and require quantification with qual ity control checks (e.g., sample replication). The assessment of operating parameters will primarily support design optimization, which is considered to be less critical. As a result, a qualitative engineering evaluation of operating parameters is required with a limited amount of quantification.

The test plan includes a combination of lower level (Levels I and II) and higher level (Levels III and V) analyses to obtain the needed data in a cost-effective manner. Field screening and field analysis techniques (Levels I and II) will be used for dafly monitoring requirements or measurements to ensure quick turn-around times required for process control. A more limited number of confirmatory Level III and $V$ analyses are identified for critical information (e.g., pre- and post-treatment uranium and ${ }^{\circ} \mathrm{TC}$ concentrations). Specific DQOS for the laboratory- and pilot-scale treatability tests are developed in Tabler 3-1 and 3-2, respectively. Analytical levels specified in the test plan are based on McCain and Johnson (1990).

\subsection{DATA INTERPRETATION}

It is anticipated that the results of the treatability test, including the laboratory-scale testing, will be assessed and interpreted using appropriate, standardized methods in the areas of logic, mathematics, and statistics. For example, computerized modeling might be useful in identifying or assessing individual or combined effects of variations in operating parameters (e.g., flow rates, $\mathrm{pH}$ ) and/or influent constituent concentrations (e.g., nitrates, sulfates, carbonates) on the effectiveness of treating the primary contaminants.

In general, data interpretation will follow guidel ines recommended by the EPA (EPA 1992). For example, laboratory data will be summarized and checked for precision, accuracy, and completeness in terms of the DQOS specified in Section 3.2. Data from a series of similar samples will be compared with the associated test operating parameters (e.g., flow rate, influent contaminant and constituent concentrations) to identify and quantify significant trends or inconsistencies.

Because data will represent discrete samples, some interpolation and/or extrapolation from sample analytical data may be required. For example, it is unlikely that effluent samples will be collected at times that coincide with uranium or $\%$ c resin breakthrough, so sample concentrations will not be directly comparable to the concentrations predicted for actual uranium and 9 Tc breakthrough. Thus, the breakthrough times would have to be interpolated between two data points. 
Data interpretation will focus on assessing and extrapolating pilotscale test results to support the test performance objectives defined in Section 3.1. It is not possible to define the sequence, format, or scope of interpretation before data are avaliable and their quality and future uses are established. However, it is possible to suggest potential interpretations based on knowledge of previous Hanford Site treatability testing, previous ion exchange testing at other sites, and potential requirements for optimizing and scaling up the treatment system. In terms of the three test performance objective categories, the following examples represent some of these potential interpretations:

\section{- Effectiveness}

- For predicting a cost/benefit ratio for ion exchange or for comparing ion exchange with other treatment technologies, it may be necessary to interpret pilot-scale results in terms of a treatment cost factor stated in dollars per quantity of uranium and/or ${ }^{\circ} \mathrm{TC}$ removed. This treatment cost factor could be generated by combining cost and performance factors such as resin capacity (e.g., ibs of uranium or ${ }^{9} \mathrm{Tc}$ per $1 \mathrm{~b}$ of spent resin), resin removal efficiency (e.g., average percentage of influent uranium or $99 \mathrm{Tc}$ removed), fresh resin purchase and installation costs, treatment system installation and operating costs, and spent resin disposal cost.

- It may be necessary to correlate resin capacity and removal efficiency with groundwater flow rate through the system configuration and then extrapolate that correlation to support decisions associated with extending the duration or expanding the capacity of treatment. An extrapolation of this type could be useful in evaluating tradeoffs among design options, for example, higher flow rate, reduced treatment duration, and reduced removal efficiency versus lower flow rate, extended treatment duration, and increased removal efficiency.

- Ion exchange applications are subject to a chromatographic effect whereby fluctuations in influent concentration can cause some fraction of adsorbed ions to desorb and enter the effiuent stream. This effect can be very important in designing treatment systems to meet effluent limits of treatment goals while accommodating wide fluctuations in influent contaminant concentrations. For treatability test samples, comparisons may be made between uranium and $9 \mathrm{TC}$ removal efficiencies and previous influent concentrations to establish the presence or absence of significant chromatographic effects.

- Operating Parameters

- Data concerning specific functions performed by pilot-scale operating and maintenance personnel, in combination with radiation monitoring results, could be evaluated using 
standardized hazards-analysis techniques to predict the operating reliability and safety anticipated from a larger scale and/or longer duration treatment system.

- Extrapolating the free moisture content of spent resin versus time allowed for draining could provide important guidance for designing full-scale spent resin handling facilities to meet anticipated waste disposal criteria concerning free liquids.

- Resource Requirements

- It may be necessary to assess the allocation of operating and maintenance labor costs to various broad categories of activity to guide designers in establishing parameters (e.g., minimum staffing requirements, cost-effective degree of automation) for scaling up a treatment system.

- Removal of total suspended solids could be correlated with pressure drop across the ion exchange columns to demonstrate that a larger filter pore size might be used, thus decreasing the cost of purchasing and instaliing new filter cartridges and removing and disposing dirty cartridges.

- A comparison could be made between the precision and accuracy of field and onsite laboratory analyses and those of confirmatory, offsite analyses to indicate whether the number of confirmatory analyses can be reduced, thus decreasing cost and operating complexity.

\subsection{ADOITIONAL DATA USES}

In addition to meeting specific treatability test objectives, these data may also be used to satisfy other data needs or to support other interim action decisions including the following:

- occupational health and safety

- risk assessment

- identification of additional characterization needs

- interim action design and objectives

- monitoring during interim actions

- additional treatability tests. 
DOE/RL-93-105

Rev. 0

Table 3-1. Data Quality Objectives for Laboratory-Scale Testing of Ion Exchange Resins.

\begin{tabular}{|c|c|}
\hline Activity & $\begin{array}{l}\text { Determine the preferred test chemistry of ion exchange resin } \\
\text { which is suitable for use in removing uranium and "Tc from } \\
\text { groundwater through laboratory testing. }\end{array}$ \\
\hline Objectives & $\begin{array}{l}\text { Identify the preferred ion exchange resin(s) effective at } \\
\text { capturing uranium and "Tc from groundwater. samples. Assess } \\
\text { nitrate removal capability of preferred resin. }\end{array}$ \\
\hline \multicolumn{2}{|c|}{ Prioritized Data Uses } \\
\hline & $\begin{array}{l}\text { To support pilot-scale treatability process design (i.e., } \\
\text { resin selection). }\end{array}$ \\
\hline \multicolumn{2}{|c|}{ Appropriate Analytical Level or Implementation Guidelines } \\
\hline & $\begin{array}{l}\text { Uranium and "Tc concentrations will be determined using a } \\
\text { liquid scintiliation analyzer (Level V). Level II analyses } \\
\text { will be used for nitrate. }\end{array}$ \\
\hline \multicolumn{2}{|c|}{ Parameters to be Obtained } \\
\hline & $\begin{array}{l}\text { - Concentrations of primary contaminants and nitrate } \\
\text { pH, temperature } \\
\text { Batch equilibria } \\
\text { - Kinetics, rate of uptake }\end{array}$ \\
\hline \multicolumn{2}{|c|}{ Required Detection or Measurement Limits } \\
\hline Critical Sam & $\begin{array}{l}\text { or Values } \\
\text { - Uranium and "Tc, concentrations of pre- and post- } \\
\text { treatment samples. }\end{array}$ \\
\hline Constraints & $\begin{array}{l}\text { - Representative groundwater samples are required. } \\
\text { Resins chosen for test ing should be effective at } \\
\text { adsorbing uranium and TC from groundwater having a pH } \\
\text { range of } 5 \text { to } 9 \text {. }\end{array}$ \\
\hline
\end{tabular}


DOE/RL-93-105

Rev. 0

Table 3-2. Data Quality Objectives for 200-UP-1 Pilot-Scale Groundwater Treatability Test. (Sheet 1 of 4)

Activity

Pilot-Scale Treatability Test

Objectives

Assess effectiveness, operating parameters, and costs associated with ion exchange to remove uranium and ${ }^{9} \mathrm{Tc}$ from extracted groundwater.

Prioritized Data Uses

Priority data uses are to support the selection of a preferred alternative for remediating the IRM plume.

Appropriate Analytical Level or Implementation Guidel ines

Level I and II screening analyses will be used for process monitoring. As a minimum, uranium, ${ }^{9} \mathrm{Tc}$, and nitrate concentrations will be verified by $l$ imited Level III or $V$ analyses. No validation (Level IV) data will be required since only interim remedial decisions are being made.

Parameters to be Obtained

- Effectiveness:

- Influent and effluent concentrations or primary contaminants (uranium, ${ }^{9} \mathrm{Tc}$ ) and secondary contaminant (nitrate)

- Operating Parameters:

- Process chemistry (e.g., total suspended solids, dissolved oxygen, calcium carbonate, chloride, nitrate, phosphate, sulfate)

- Flow rate

- pH, temperature, turbidity

- Operating pressures, both differential and point

- Chemical additive requirements 
Table 3-2. Data Quality Objectives for 200-UP-1 Pilot-Scale Groundwater Treatability Test. (Sheet 2 of 4)

\section{Parameters to be Obtained (cont.)}

- Resource Needs:

- Equipment/materials

- Personnel and maintenance requirements

- Secondary waste volumes and characteristics

- Poiver and chemical usages

- Operating efficiency

- Health and safety requirements, including field radiation monitoring

- Other cost elements, (e.g., mobilization, sample transport, analytical services, decontamination, residuals transport/treatment/disposal)

Required Detection or Measurement Limits

- Effectiveness

Analytical detection 1 imits for uranium and ${ }^{9} \mathrm{Tc}$ must be able to detect expected effluent concentrations after $90 \%$ removal. Accuracy should be sufficient to support calculation of removal efficiency to $\pm 1 \%$. Other supporting documentation such as equipment data sheets may also affect final DQOS. Detection limits and other PARCC parameters are specified in the quality assurance project plan (QAPJP) included with the 200-UP-1 Operable Unit Work Plan. The following are DQOS for Level III analyses:

\begin{tabular}{|c|c|c|c|c|}
\hline Perrmate & Method & CRPL/GROL" & Precision & Acqurey \\
\hline $\begin{array}{l}\text { Urenium } \\
\text { (Total) }\end{array}$ & epA 9og" & $0.1 \mathrm{mg}$ & $220 x$ & $73-125 x$ \\
\hline$\infty_{\text {Te }}$ & EPA $901.1 "$ & $150 \mathrm{pCi} / \mathrm{L}$ & $220 x$ & $75-123 x$ \\
\hline Mitrote & 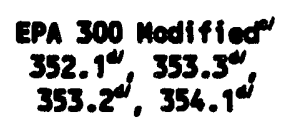 & $100 \mathrm{mg} / \mathrm{L}$ & 22000 & $75.125 x$ \\
\hline
\end{tabular}

\section{- Operating Parameters}

Process chemistry will be measured primarily to detect significant and/or unanticipated secondary impacts on system operation and efficiency. Analytical protocols will follow established vendor standards, industrial standards, or EPA practices. Other operating parameters will be measured as follows: 
Table 3-2. Data Quality Objectives for 200-UP-1 Pllot-Scale Groundwater Treatability Test. (Sheet 3 of 4)

\begin{tabular}{|c|c|c|c|}
\hline Parameter & Instrument & Range & Accuracy \\
\hline Flow rate & meter & $0-100 \mathrm{gal} / \mathrm{m}^{+n}$ & $\stackrel{ \pm 1}{\text { gal/min }}$ \\
\hline pH & probe & $0-14$ & \pm 0.1 \\
\hline Temperature & $\begin{array}{l}\text { thermocouple } \\
\text { or thermometer }\end{array}$ & $0-100^{\circ} \mathrm{C}$ & $\pm 1{ }^{\circ} \mathrm{C}$ \\
\hline Pressure drop & $\begin{array}{l}\text { transmitter } \\
\text { or gauge }\end{array}$ & $0-30 \mathrm{lb} / \mathrm{in}^{2}$ & $\frac{ \pm 0.5}{16 / \text { in }^{2}}$ \\
\hline Point pressure & $\begin{array}{l}\text { transmitter } \\
\text { or gauge }\end{array}$ & $0-100 \mathrm{lb} / \mathrm{in}^{2}$ & $\pm 11 b /$ in $^{2}$ \\
\hline Turbidity & meter & $0-100$ NTU' & \pm NTU \\
\hline
\end{tabular}

- Resource Needs

Resources will be monitored in accordance with normal recordkeeping practices (e.g., inventory, manhours) specific to each resource type. EPA guidance cails for an accuracy of $+50 \%$ to $-30 \%$ in estimating costs for implementation.

\section{Critical Samples or Values}

- Uranium and "Tc concentrations in influent and effluent streams at a frequency proportional to the rate of change in the primary contaminants

- Chemical and radiological concentrations in spent resins and discarded filter cartridges

- Operating costs (e.g., materials, personnel)

- Secondary waste disposal costs. 
Table 3-2. Data Quality Objectives for 200-UP-1 P1lot-Scale Groundwater Treatability Test. (Sheet 4 of 4)

\section{Constraints}

- It is necessary that resin breakthrough be measured in a timely manner for both uranium and "Tc.

- Representative samples are required of process water streams, discarded filter cartridges, and spent resin.

- Some resin and filter cartridge samples may have high radionuclide content and may require special sampling and handling methods.

a) CRDL refers to the Contract Required Detection Limit specified in the USEPA Contract Laboratory Program Statement of Work for Inorganics Analysis (EPA 1991a); CRDL refers to the Contract Required Quantitation Limit specified in the USEPA Contract Laboratory Program Statement of Work for Organics Analysis (EPA 1991b)

b/ Prescribed Procedures for the Measurement of Radioactivity in Drinking Water (EPA 1982).

c/ Method specified is from Determination of Inorganic Anions in Aqueous and Solid Samples of Ion Chromatography (Lindahi 1984), and is a modification of EPA Method 300.0

d) Methods for Chemical Analysis of Water and Wastes (Kopp and McKee 1983).

e/ NTU = nethelometric turbidity unit(s). 
DOE/RL-93-105

Rev. 0

\subsection{TREATABILITY TEST DESIGN AND OPERATING REQUIREMENTS}

The activities in this section are designed to fulfill test performance objectives and DQOS discussed in Section 3.0 of this document.

\subsection{LABORATORY TREATABILITY TESTING}

Laboratory treatability tests will be completed to provide information for the evaluation and selection of one or more ion exchange resin effective in removing the primary contaminants, uranium and ${ }^{9} \mathrm{TC}$, from 200-UP-1 Operable Unit groundwater. The laboratory tests will also assess resin performance for the removal of secondary contaminants, including nitrate. A maximum of approximately five or six resins are anticipated to be tested, such as: DOWEX 21K and DOWEX 21K XLT (Trademarks of Dow Chemical Company, Midland, Michigan); IRC-718 (Trademark of Rohm \& Haas, Philadelphia, Pennsylvania); Luwatit MP500-FK (Trademark of Mobay Chemical Company, now Miles, Inc., Pittsburgh, Pennsylvania); and Reillex HP and Reillex HPQ (Trademarks of Reilly Industries, Indianapolis, Indiana). Resins will be tested in the Iaboratory before being used in the pilot-scale treatment system. The selected or preferred resin(s) must have a high affinity for removing primary contaminants from the groundwater over the anticipated $\mathrm{pH}$ range, should demonstrate rapid adsorption of the primary contaminants, should display appropriate physical characteristics, and should not impose a high pressure drop due to small particle size in a column flow operation. In addition, the potential effects of secondary contaminants, such as nitrate, should be considered for the selected or preferred resin(s) (e.g., impacts on primary contaminant adsorption capacity, impacts on adsorption rates).

The physical characteristics of different types of ion exchange resin may be of concern during the treatability test. Therefore, the swelling potential, moisture content, and density of the different ion exchange resins will be assessed during laboratory testing so that the physical properties can be addressed during final design of the pilot-scale treatment system. Ion exchange resins swell due to water being captured within the resin structure. Depending on the amount of water within each different resin, the material will swel1, increase in moisture content, and increase in density. The magnitude of the potential change in each of these physical properties will be monitored during laboratory testing and the results incorporated into the design of the treatment system as appropriate. Since onsite regeneration will not be performed during the treatability test, the impact of swelling on the life of the resin due to attrition and breakage does not need to be considered.

A significant body of data, including uranium testing at 100-HR-3 (WHC 1994). and knowledge of uranium chemistry, has been used as part of the assumptions made for preliminary resin identification. Laboratory testing will be used to confirm and optimize resin selection prior to and in parailel with pilot-scale testing. Resins that satisfy the performance criteria identified above (e.g., high affinity for primary contaminants, appropriate physical characteristics) based on laboratory testing will be candidates for pilot-scale testing. 
DOE/RL-93-105

Rev. 0

Samples of groundwater from the IRM plume will be furnished for conducting these tests. Testing will include:

- Equilibrium Distribution Measurements - Contact appropriate volumetric samples of preconditioned groundwater (filtered and analyzed for uranium, ${ }^{\circ} \mathrm{Tc}$, and secondary contaminants, including nitrates) that have been adjusted to specific $\mathrm{pH}$ values in the range of 5 to 8 with known amounts of resin(s) to perform batch equilibriums. The batch equilibriums should be performed in duplicate or triplicate over 24-hr periods. Afterward, the samples will be centrifuged or filtered as appropriate and the solution will be analyzed for "post-contact" uranium, "TC, and secondary contaminant (e.g., nitrate) concentrations. The distribution coefficients will then be calculated using these results.

- Flow-through Column Measurements - Once the equilibrium measurements have screened candidate resins to determine a preferred resin $(s)$, small-scale column tests will be performed using known amounts of resin in a small 2- to $3-\mathrm{cm}$ diameter column. Single run tests will be conducted on candidate resins, although each resin may also be tested with additional single runs at various $\mathrm{pH}$ values.

Groundwater will be passed through separate columns at various flow rates in an effort to determine the kinetics (i.e., rates of adsorption) for the particular resin(s). The kinetics will be determined by comparing the influent concentrations $\left(C_{0}\right)$ with the effiuent concentrations (C) over time for contaminants.

A minimum of one duplicate sample analysis will be performed for every 20 samples analyzed.

Initial laboratory testing will be performed to identify a preferred resin for pilot-scale test startup. Laboratory tests will continue after pilot-scale test startup to further evaluate alternative candidate resins, and should be completed shortly after the pilot-scale treatment test is initiated. Information gathered during parallel laboratory and pilot-scale testing may result in identifying alternative resin(s) that would be more effective than the initially selected resin. Should this occur, the alternative resin(s) will replace the initially selected resin and will be tested in the ion exchange pilot-scale system.

\subsection{PILOT-SCALE TREATABILITY TEST DESIGN}

\subsubsection{Treatment Process Description}

A conceptual process flow diagram for the 200-UP-1 Operable Unit pilotscale treatment system is shown in Figures 4-1 and 4-2. The treatment system will be run continuously each operating day for approximately $6 \mathrm{hr}$ at a design flow rate of approximately $50 \mathrm{gal} / \mathrm{min}$. Groundwater will be withdrawn from an extraction well and pumped to an influent storage tank. Since the existing extraction rate is expected to produce no more than $20 \mathrm{gal} / \mathrm{min}$, the influent storage tank decouples the groundwater extraction operation from the treatment 
DOE/RL-93-105

Rev. 0

process. The extraction well pump will operate continuously to fill the storage tank, thereby providing sufficient volume of groundwater for the treatment system to operate at the design flow rate. Groundwater will be pumped from the storage tank through particulate filters for removal of suspended solids, then through the ion exchange system for removal of uranium and ${ }^{\mathrm{T}} \mathrm{T}$, and finally to an effluent storage tank. The effluent storage tank will be used to transfer the treated groundwater to the aquifer return well at rates similar to withdrawal from the extraction we 11 on a continuous basis. In addition, if it is determined that the treated effluent does not meet discharge objectives (i.e., $90 \%$ removal of primary contaminants), the groundwater can be returned for additional treatment.

Ion exchange is a technology that removes fons from solution by adsorption on a solid media (1.e., resin). When groundwater is passed through an ion exchange column, fonic species in groundwater exchange with ions on the media until equilibrium is attained or a predetermined percent breakthrough of a primary contaminant is achieved. Ion exchange resins have a finite adsorption capacity based on available exchange sites on the resin. Uranium and Tc may compete with other ions found in groundwater for these exchange sites. Although treatment effectiveness impacts of secondary contaminants, such as nitrate, will be assessed during laboratory and pilot-scale testing, secondary contaminant (e.g., nitrate) removal is not a primary objective of the treatability test program. Therefore, the ion exchange resins that will be used for this treatability study will be chosen for their preferential ability to selectively adsorb uranium and 90 over nitrate and other potential interfering lons. The selected IX resin will most likely remove nitrate for a brief period (e.g., approximately two days) before saturating the resin's nitrate exchange capacity. Once saturation has occurred, nitrate concentrations will no longer be reduced, but uranium and ${ }^{\circ} \mathrm{TC}$ should cont inue to be adsorbed by the IX resin. Since the estimated IX resin life is approximately two weeks to two months, the overall nitrate removal is expected to be inconsequential.

Radionuclide concentrations are several orders of magnitude below those of the major lonic species (e.g., nitrates, sulfates), thus compounds other than urantum and Tc may determine resin exhaustion rates. When the resin is "spent" (exceeds its adsorption capacity), breakthrough or detection of primary contaminants in the column effiuent will occur. At that point, the spent resin will require replacement or regeneration. During the treatability test, spent resin will be replaced rather than regenerated to minimize the volume of aqueous secondary wastes and because there is no planned use for the eluted radionuclides resulting from the regeneration cycle.

The ion exchange treatment system will consist of two ion exchange columns operated in series flow arrangement, and a spare or backup column as shown in Figure 4-2. The lead or first column will provide bulk removal of the primary contaminants and the lag or second column will provide removal of the residual primary contaminants as breakthrough of the lead bed is approached. When breakthrough of the lead bed occurs, it will be taken out of service for resin replacement. The lag bed will be then moved into the lead position and the spare bed will be brought online in the lag position. This configuration will allow the plant to continue to operate while resin in the "spent" column is replaced. The ion exchange process will require little 
automation. Successful operation is dependent on an adequate effluent monitoring program to determine when breakthrough of the resin has occurred.

A chemical addition system, as shown in Figure 4-2, may be required as part of the ion exchange treatment process to achieve the desired contaminant removal efficiencies. Some ton exchange resins optimally load radionuclides in the $\mathrm{pH}$ range of 5 to 7 . Chemical addition may be used to adjust the influent $\mathrm{pH}$ to a range that is optimum for the particular ion exchange resin. Neutralization of the fon exchange effluent may be required to readjust the $\mathrm{pH}$ to match the groundwater $\mathrm{pH}$ before the treated effluent can be returned to the aquifer (but only if the $\mathrm{pH}$ was adjusted or changed during the treatment process). However, it is preferred to select a resin that will adsorb at the expected groundwater influent $\mathrm{pH}$ to simplify the process.

\subsubsection{Pllot-Plant Treatment Equipment}

Treatment plant equipment will be mounted on skids to enable transportation by a flatbed truck to the test site. Influent groundwater from the influent storage tank will be filtered using cartridge filters prior to the ion exchange system. The feed pumps to the treatment system will be interlocked by level switches in the influent and effluent tanks to prevent overflows and protect the pumps at low flow rates. As a secondary overflow precaution, the infiuent and effluent tanks may have outlet pipes near the top of each tank to redeliver stored water to the extraction well. Flow indicating totalizers will be used to monitor the extraction well, process treatment, and return well flow rates and total volumes.

The ton exchange system will be piped to allow for series flow. Using existing ion exchange columns avajlable as surplus equipment and 1 imiting flow rate to a maximum of $5 \mathrm{gal} / \mathrm{min}-\mathrm{ft}^{2}$ will result in a minimum empty bed contact time of silghtly more than $6 \mathrm{~min}$. Differential pressure indicators will be installed to measure the pressure drop across each fon exchange column.

If $\mathrm{pH}$ adjustment of the ion exchange feed is required, a neutralization system would also be required to adjust the pH of the treated effluent back to neutral before discharge to the effluent holding tank. The pH adjustment and neutralization systems would consist of chemical storage tanks for acid and base solutions, a mixing tank, and chemical metering systems for both the acid and base adjustments controlled by $\mathrm{pH}$ controllers. In addition, a transfer pump would be required to transfer the neutralized effluent to the effluent storage tank. The treatment system has been designed to allow for sidestream withdrawal of groundwater to accommodate the testing of innovative technologies.

\subsubsection{Groundwater Withdrawal and Return}

Since the existing wells are somewhat limited in number and flow rate, and since the pilot-scale treatment system has an operating rate more than twice the expected well withdrawal rate $(50 \mathrm{gal} / \mathrm{min}$ process rate versus $<20 \mathrm{gal} / \mathrm{min}$ withdrawal rate), the strategy for extraction of the groundwater for treatment and return to the aquifer dictates that the wells be decoupled 
from the treatment system with the use of surge storage tanks. Groundwater will be withdrawn from the extraction well on a continuous basis, filling a large (up to approximately 20,000 gal) storage tank; the treatment system will be operated on the day shift under engineering support (approximately $6 \mathrm{hr}$ processing approximately 18,000 gal); the treated effluent will be transferred to an effluent storage tank and returned to the aquifer at approximately the same rate of withdrawal. Level controls will be interlocked with the well punps to prevent overflowing the storage tanks.

Prior to returning the treated water to the aquifer, it will be filtered to remove any solids that may occur from biological activity in the effluent storage tank. In addition, the system includes the ability to add sodium sulfite to the aquifer return flow at the wellhead to scavenge dissolved oxygen, but only if this is determined to be necessary to mitigate biological activity and possible plugging of the disposal well.

\subsubsection{Support Components}

The skid-mounted process treatment plant equipment will be placed within a frame-supported fabric structure to provide protection from the weather. The interior of the structure will be heated by propane heaters to avold the need to winterize all plant components, and some of the process components may be heat traced and insulated for freeze protection.

The proposed test site location will not be served by existing utflities. Portable generators, fuel tanks, air compressors, lighting, and tollets must be provided. A water tank will be used at the site for personnel decontamination, chemical makeup water, and slurrying resin in and out of the Ion exchange colums. Bottled drinking water will be provided at the site in an office/supply trailer. Portable eyewashes and showers will also be placed at each test site. Figure 4-3 indicates the proposed locations for many of these supporting facilities.

Small leaks and drips may occur during system operation due to equipment changeout, hose and pipe connect and disconnect, and related activities. All leakage and drippage will be contained and returned to the treatment system process flow or to the effluent collection tank.

\subsection{TREATABILITY TEST SYSTEM OPERATION}

\subsubsection{Fabrication and Setup}

The skid-mounted treatment plants and equipment will be fabricated in Hanford shops or w111 be procured directly from vendors. At the completion of the detalled design, the procurement of treatment plant components will be initiated. System components will be selected and/or shop fabricated to be in conformance with relevant Occupational Safety and Health Administration (OSHA) and National Electrical Code (NEC) standards to minimize the need for modifications in the field at the test site. Components will be mounted on steel skids to allow for easy transportation to the test site and to minimize 
DOE/RL-93-105

Rev. 0

test site preparation requirements. Prior to transportation to the test sites, acceptance tests will be performed on the system. Acceptance test procedures will be prepared in accordance with WHC Standard Engineering Practices (WHC 1988a, AppendiX M). Acceptance test procedures will be used to demonstrate that the system is assembled and working as intended prior to release to the test site. Final piping and electrical connections between the plant skids will be made at the test site.

Prior to startup of the plants a readiness review will be performed using the process described in Environmental Investigation Instruction

(EII) 1.13, Environmental Readiness Review (WHC 1988b). Completing the readiness review and other pre-test activities and checklists will lead to the start of the treatability tests, and meet the Tri-Party Agreement Milestone M-13-02A, "Begin pllot-scale pump and treat operattons for 200-UP-1 30 days after the Lialted Field Investigation Workplan is approved but no sooner than March 31, 1994" (Change Number M-13-93-03).

\subsubsection{Operation}

The treatablifty test plans have been developed and the pilot-scale plants designed to allow for modifications in response to test observations and process monitoring results. Modifications may include changes in the operating parameters, plant configuration, or selected resin.

Standard operating procedures will be prepared for the pilot-scale test and varled, if necessary, using the observational approach. The treatment system will be operated for approximately $6 \mathrm{hr} / \mathrm{day}$ during the course of the pllot test program. While the treatment system is operating, an operator will remain onsite to monitor the process. Operation of the groundwater extraction and return systems will not be tied directly to that of the treatment system. Groundwater extraction and return will be automated for safety shutdowns and will operate continuously, and without constant operator oversight.

Data on the effectiveness of the treatment process will be collected throughout the test program. If the plant does not achieve the desired treatment levels, operating parameters will be changed or the plant will be modified until treatment is either successful or is determined to be ineffective. The successful demonstration of the treatment system effectiveness inplies that urantum and $T c$ continue to be detected in the groundwater influent to the pilot plant.

Full evaluation of the treatability test will require that the ion exchange columns be operated to breakthrough so that an estimate of the adsorption capacities of the ion exchange resin for both uranium and "Tc can be made. The fon exchange systems have been designed to enable changes in operating conditions or to allow for plant modifications. It is initially proposed to operate the system as two ion exchange columns in series using a single type of lon exchange resin (although other resin[s] may be tested if laboratory-scale tests identify better resins that are more preferable than the initially selected resin). Under this initial operating configuration the 
DOE/RL-93-105

Rev. 0

system flow rate (column residence time) is the only operating parameter that can be varied.

During the operations of the pllot-scale test, secondary wastes w1ll be generated which will require characterization for disposal. These wastes include filter cartridges, spent resin, and any backwash water that cannot be returned to the influent storage tank for treatment. Samples of the resin may be evaluated for regeneration, or alternatively may be used to evaluate a resin drying system that would allow the material to be disposed of as a solid waste.

\subsubsection{Process Haste Management}

Secondary wastes will be disposed and/or stored onsite at locations approved to receive the types of wastes generated during treatability testing. Appendix $A$ of this test plan provides a waste control plan (WCP) for handling and disposition of these secondary wastes. Ecology is required to approve the WCP prior to initiating the pilot-scale test. Laboratory wastes will be disposed of in accordance with existing waste-handling procedures.

Field testing will generate secondary wastes primarily through the replacement of spent resins, or backflushing, conditioning or rinsing of the resins in the ion exchange columns. Aqueous wastes will be treated by the pilot plant. All other wastes, and aqueous wastes that cannot be treated by the plants, will be disposed of per WHC policy for onsite disposal according to waste type (WHC 1988b).

\subsubsection{Process Monitoring}

Process monitoring will be performed to control and operate the treatment process and to gather performance data. The effectiveness of the treatment system will be primarily demonstrated through laboratory Level III and V chemical analyses of process samples. Samples from the $p l a n t$ influent and effluent, and the influent and effluent from the lead fon exchange column will be taken. Operating parameters such as $\mathrm{pH}$, temperature, and turbidity will al so be monitored because of their potential impact on the treatment process. The frequency of sampling will be related to the observed rate of change of contaninant concentrations in the untreated groundwater, and the estimated breakthrough $t$ imes for the ion exchange columns. Appendix $B$ of this test plan presents the process SAP that will be followed.

In addition to laboratory Level III and $V$ chemical analyses to determine treatment effectiveness, process monitoring will be performed using field screening analysis to provide quick turn-around times. Online monitors will be used whenever possible. Radiation monitors will be used throughout the test to refine operational procedures and specify personnel protective equipment.

Pressure drops across ion exchange beds will be monitored throughout the tests to assess the buildup of suspended solids on the resin and the need for backwashing. Solids generation and accumulation in different parts of the 
DOE/RL-93-105

Rev. 0

plant will be documented. An accounting of all secondary waste generation will be made. Maintenance during operation of the pilot plant would be documented. Chemical addition rates and volumes will also be documented. The volume of groundwater pumped to the treatment train and returned into the aquifer will be measured with flowmeters equipped with totalizers and documented. Aquifer level drawdown will be monitored during test performance and aquifer level recovery will be observed when groundwater pumps are shut off.

A tracer, lithium bromide, will be used to assess if a recirculation cell has been established between the extraction and return wells. This information will be used to support operational decisions regarding well use. Lithium bromide will be added to the post-treatment (effluent) stream prior to returning to the aquifer. A target bromide concentration of $50 \mathrm{ppm}$ will be achieved by introducing a solution of lithium bromide into the effluent stream. Bromide concentrations will then be monitored for in the pretreatment (influent) stream using a bromide specific electrode. As a minimum, bromide concentrations will be measured weekly.

\subsection{TEST MELL SELECTION}

Groundwater that is representative of the IRM plume must be supplied to the treatment system at sustainable and appropriate flow rates to meet the objectives of the test. A continuous groundwater extraction rate of approximately 15 to $20 \mathrm{gal} / \mathrm{min}$ is required to meet the process goals of the treatment system. Following treatment, groundwater will be returned to the aquifer via return wells at rates similar to extraction and within the IRM plume boundary.

An evaluation of existing groundwater wells located in the vicinity of the IRM plume was made for the purpose of recommending appropriate extraction and return wells to support the pilot-scale treatability test. Criteria were developed to facilitate the evaluation and included the following:

- relatively high concentrations of uranium and ${ }^{90} \mathrm{TC}$

- minimum expected impacts on other plumes, if present

- minimize impacts to other well users

- availability of additional wells in the vicinity of the test wells for monitoring the impacts of extraction and return

- type of well (screened wells preferred over slotted or perforated wells)

- wells must be open in the upper portions of the unconfined aquifer

- sufficient working room in the vicinity of the wellheads.

Based on these criteria, several wells in the vicinity of the 216-U-17 Crib were identified as candidate extraction or return wells. These wells were recommended for 1 imited field testing to assess groundwater production capacity and confirm the adequacy of the well. Field activities included a camera survey and 1 imited well production tests to predict yield and drawdown. However, not all candidate wells were tested. A candidate well was not tested if it was located in a surface radiation zone, or if it was of similar design 
DOE/RL $-93-105$

Rev. 0

and close to a well that was tested. Of those tested, only wells 299-W19-24 and 299-W19-25 were estimated to produce groundwater at acceptable rates of approximately 17 and $16 \mathrm{gal} / \mathrm{min}$, respectively. Table 4-1 summarizes well production test data presented in Data for Well Useability Tests in Support of the 200-UP-1 Treatability Program (Simpson 1994). Hell construction information for candidate wells is summarized in Table 4-2.

Wells recommended to support the pilot-scale treatability test include 299-W19-24 as an extraction well and 299-W19-25 as a return well. This configuration will minimize the potential for establishing a recirculation cell between the two wells. Both wells are located on the north side of the 216-U-17 Crib (Figure 4-3) and are screened in the upper unconfined aquifer. These wells define some of the highest, if not the highest, concentrations of uranium and ${ }^{9}$ TC associated with the IRM plume (Figures 1-2 and 1-3). Both wells are expected to have adequate production capacity. Capture zone analysis was performed for the selected pumping and return wells (Connelly 1994). Modeling results indicate that a recirculation cell will not be deveioped between the pumping and return well.

The other candidate wells located in the vicinity of the 216-U-17 Crib (299-W-19, 299-H-20, 299-W-23, 299-W-29, and 299-W-30) will be retained as alternative wells. Furthermore, it may be necessary to use two wells in combination, if a particular well is, by itself, inadequate to support the test. Conditions that may be encountered that may impact the continued use of a well include the following:

- uranium and $99 \mathrm{Tc}$ concentrations in extracted groundwater decrease to a point where they no longer meet process test requirements or are not representative of the IRM plume conditions

- establishment of a recirculation cell between the extraction and return well

- flow capacity of a well diminishes to a rate insufficient to meet process requirements.

\subsection{EROCNOUATER MONITORING}

Field activities will be conducted to monitor impacts of the pilot-scale test to the local upper unconfined aquifer. Monitoring activities include water table level measurements and groundwater sampling for chemical analyses.

The recomended wells for sampling during the pilot-scale treatability test include wells 299-W19-19, 299-W19-20, 299-W19-23, 299-W19-26, 299-W19-29, and 299-W19-30. All recommended monitoring wells are located near the 216-U-17 Crib test site (Figures 1-2 and 1-3) that locally has the highest concentrations of gross alpha, gross beta, nitrate, ${ }^{9} \mathrm{Tc}$, and uranium. Other cuntaminants that may be encountered are carbon tetrachloride, chloroform, and iodine. 
DOE/RL - 93-105

Rev. 0

\subsubsection{Requirements}

In addition to requirements identified in this document, all work will be performed in accordance with the following applicable documents and procedures:

- WHC-EP-0383, Environmental Engineering, Technology, and Permitting Function Quality Assurance Program Plan (WHC 1990)

- WHC-CM-7-7, Environmental Investigations and Site Characterization Manual (WHC 1988b)

- EII 1.5

Field Logbooks

- EII 5.1 Chain of Custody

- EII 5.4 Field Cleaning and/or Decontamination of Equipment

- EII 5.8 Groundwater Samoling

- EII 5.11 Sample Packaging and Shipoing

- EII 10.3 Purqewater Management

- WHC-CM-7-8, Volume 4, Environmental Engineering and Geotechnology Function Procedures (WHC 1992b)

- Section 2.2, "Groundwater Quality Control Sampling"

- Section 2.5, "Temperature Control of Groundwater Sample Storage Refrigerators"

- Section 5.1, "Groundwater Measuring and Test Equipment (MATE) Calibration by User"

- Section 5.2, "Groundwater M\&TE Calibration by WHC Standards Laboratory".

\subsubsection{Sampling and Analysis Plan}

Monitoring well sampling will coincide with the pilot-scale test operations. Groundwater monitoring activities will be initiated prior to start of the test to collect baseline information. Field sampling at each well will begin with well purging.

The groundwater monitoring schedule will be based on the treatment system operat ing schedule. Wells recommended for monitoring include 299-W19-19, 299W19-20, 299-W19-23, 299-W19-26, 299-W19-29, and 299-W19-30. Basel ine water table measurements and chemical analyses will be taken approximately 
DOE/RL-93-105

Rev. 0

10 days prior to the start of pilot-scale treatability testing. Water level measurements will be taken continuously for wells in the immediate vicinity of the 216-U-17 Crib, including 299-W19-19, 299-W19-20, 299-W19-23, and 299-W19-26. As a minimum, biweekly water level readings will be taken at wells 299-W19-29 and 299-W19-30. One complete set of groundwater samples will be taken before and after the pilot-scale test. Analytes will include ${ }^{\circ} \mathrm{TC}$, uranium, and nitrate.

The list of analytes is summarized in Table 4-3. Samples will be collected and handled using the protocols defined in EII 5.8, Groundwater Sampling (WHC 1988b). A field determination of nitrate (Level II) will be conducted at the site. Onsite or contract laboratory services will be used for uranium and ${ }^{9} \mathrm{Tc}$ analyses. Samples shipped should have analyses performed using Level III or Level $V$ methodologies (as applicable). Sample custody will follow procedures as outlined in EII 5.1, Chain of Custody (WHC 1988b).

\subsubsection{Quality Assurance/Quality Control Requirements}

Data quality is controlled by this document and the 200-UP-1 QAPJP (DOE-RL 1993a). The quality assurance documents that cover the test activities are the Quality Assurance Manual (WHC 1988C), and the Environmental Engineering, Technology, and Permitting Function Quality Assurance Program Plan (WHC 1990).

Quality control samples for Level III or $V$ analyses should be collected at the following frequency.

- one duplicate from one well for each scheduled round of sampling

- one split sample from one well for each scheduled round of sampling.

\subsection{HEALTH ND SAFETY}

All field personnel working to this test plan will have completed the 40-Hour Hazardous Waste Site Worker Training Program and will perform all work in accordance with the following:

- WHC-CM-1-6, Westinghouse Radiological Control Manual (WHC 1993)

- WHC-IP-0718, Health Physics Practices Manual (WHC 1988d)

- WHC-CM-4-3, Industrial Safety Manual (WHC 1987)

- WHC-CM-7-5, Environmental Compliance Manual (WHC 1988e)

- Applicable safety documentation. 


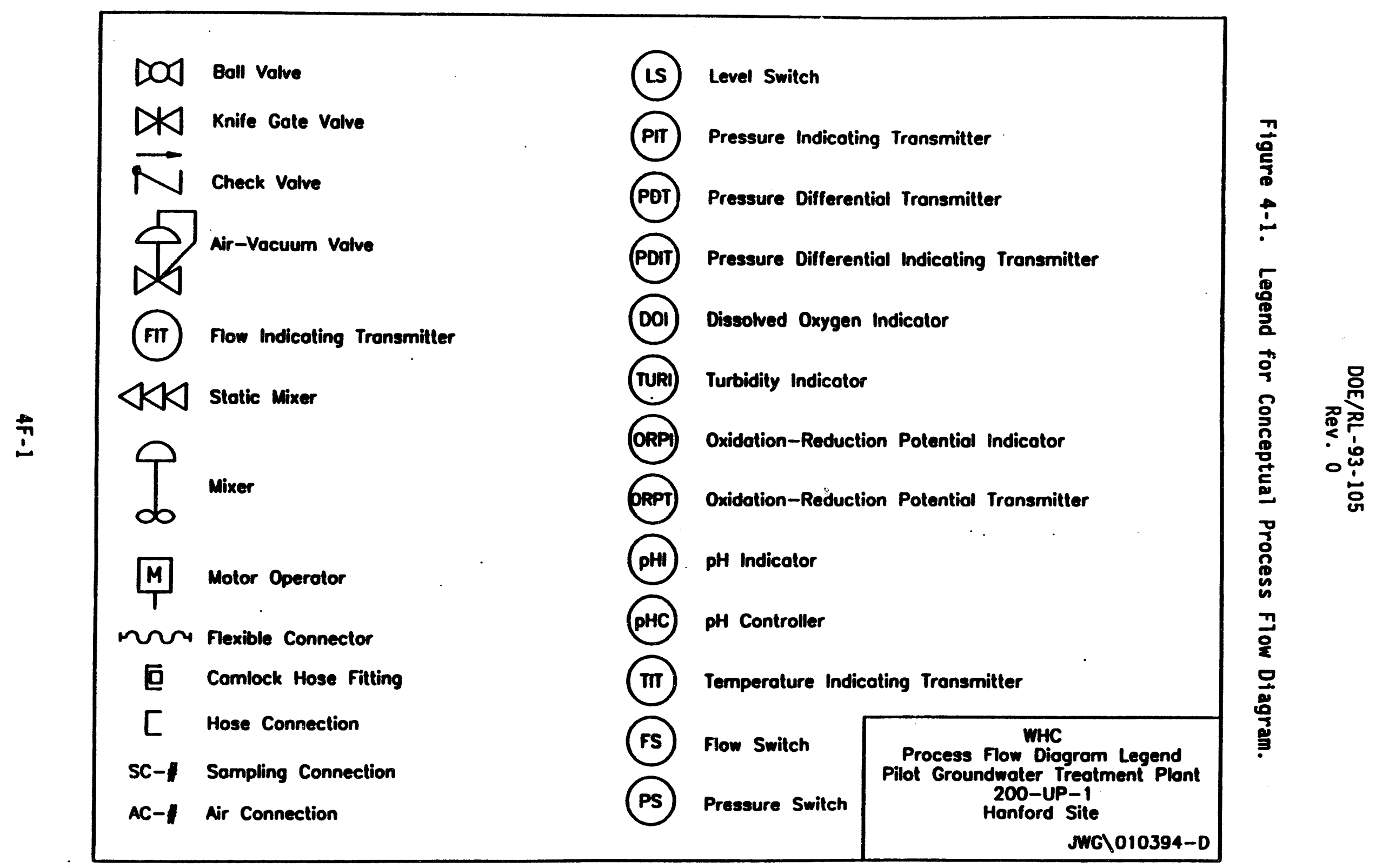




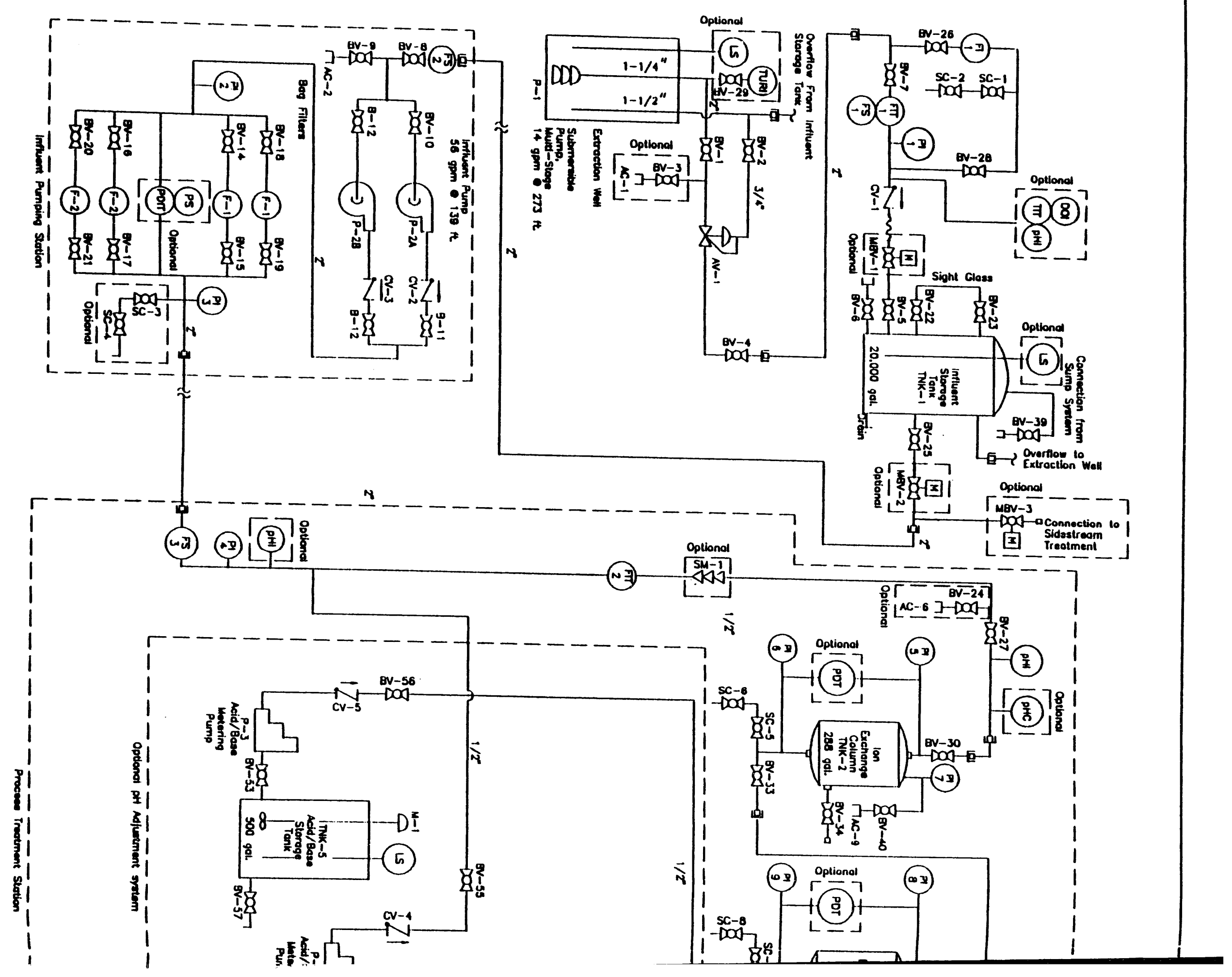


Figure 4-2. Conceptual Process Flow Diagram, 200-UP-1 Operable Unit Treatability Test.

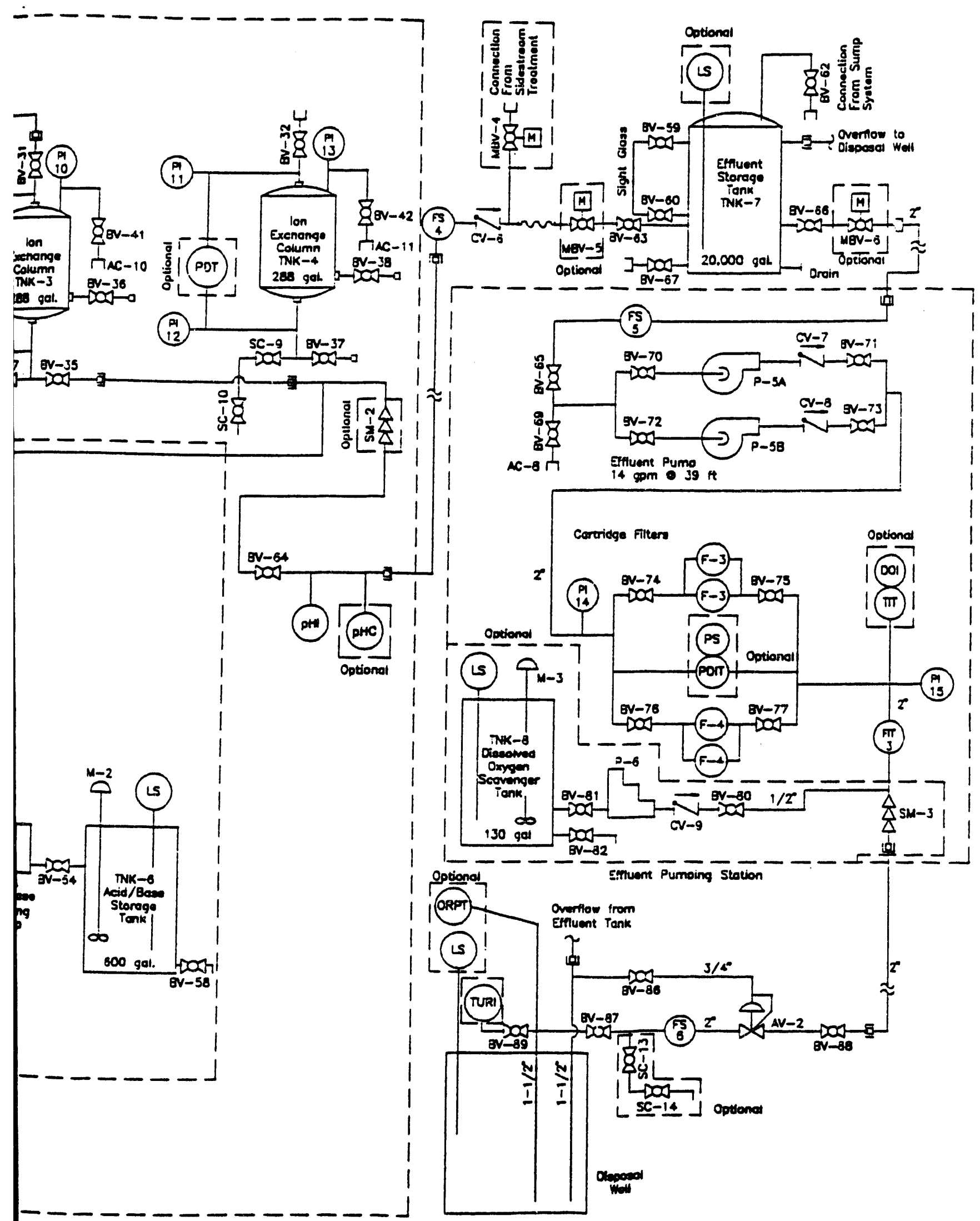


DOE/RL-93-105

Rev. 0

Figure 4-3. Proposed Site Plan for the 200-UP-1

Operable Unit Treatability Test.

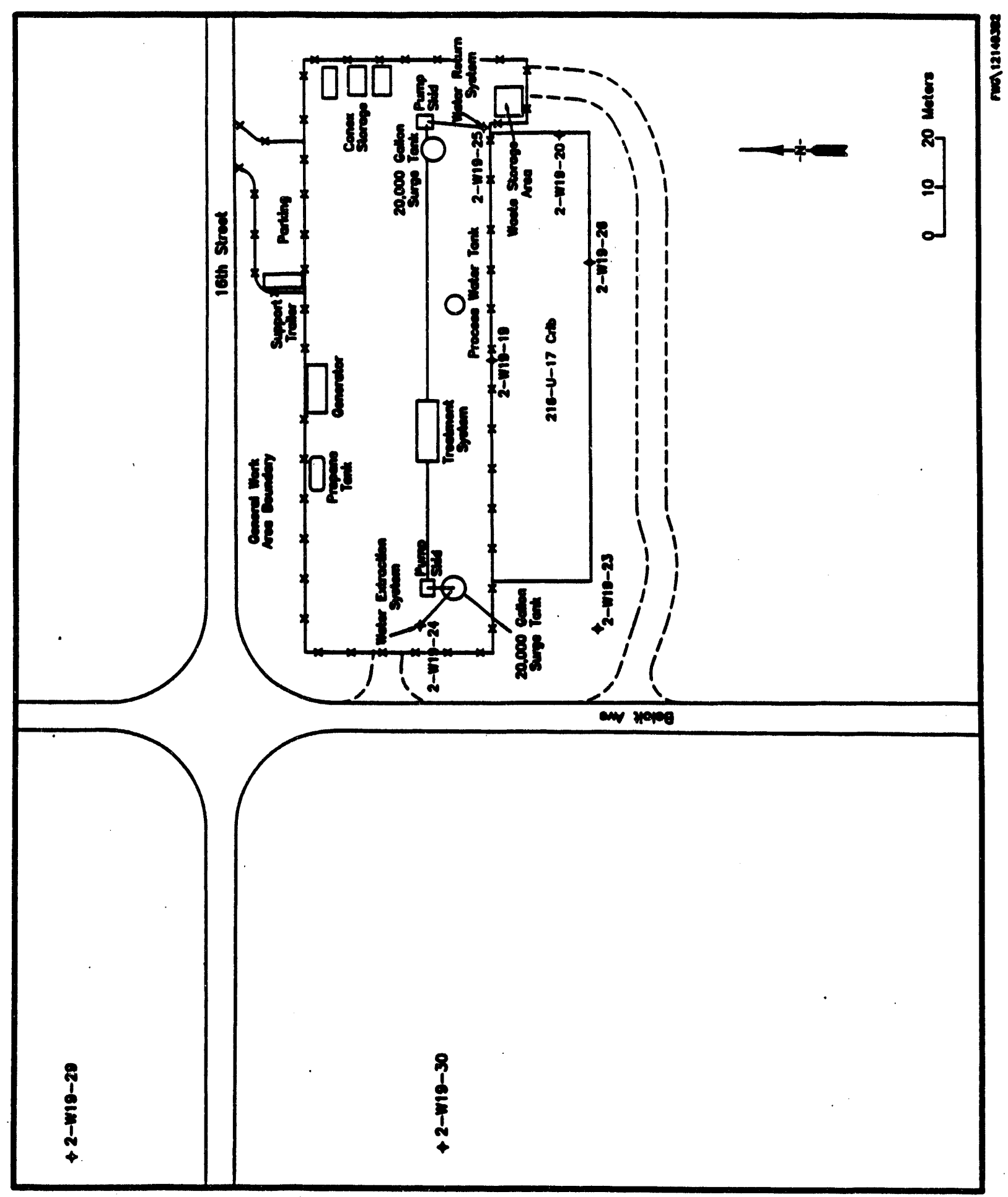


Table 4-1. Estimated Groundwater Production for the 200-UP-1 Well Usability Tests."

\begin{tabular}{|c|c|c|c|c|c|}
\hline Well & $\begin{array}{c}\text { Total } \\
\text { Drawdown, } \\
\text { ft }\end{array}$ & $\begin{array}{c}\text { Discharge } \\
\text { Rate, } \\
\text { gal/min }\end{array}$ & $\begin{array}{c}\text { Specific } \\
\text { Capacity }\end{array}$ & $\begin{array}{c}50 \% \text { of } \\
\text { Screen, } \\
\mathrm{ft}\end{array}$ & $\begin{array}{c}\text { Estimated } \\
\text { Production, } \\
\text { gal/min }\end{array}$ \\
\hline $299-W 19-23$ & 2.6 & 6.25 & 2.4 & 6.5 & 12.5 \\
$299-W 19-24$ & 1.74 & 6.25 & 3.6 & 5.8 & 16.8 \\
$299-W 19-25$ & 2.5 & 7.05 & 2.8 & 7.0 & 15.8 \\
$299-W 19-29$ & 2.2 & 6.65 & 3.0 & 5.5 & 13.3 \\
$299-W 19-30$ & 2.5 & 4.25 & 1.7 & 5.3 & 7.2 \\
\hline
\end{tabular}

- Usability tests were performed from December 2, 1993 to January 7, 1994. Usability tests were performed from December to January 1994.

Specific Capacity $=\frac{\text { Discharge Rate }}{\text { Total Drawdown }}$

Estimated Production - Specific Capacity * Screen Length

Equations are based on Data for Well Useability Tests in Support of 200-UP-1 Treatability Program (Simpson 1994).

- Estimated well production is $80 \%$ of the specific capacity. This conservative factor was added because of the short duration of the well production tests. 
Rev. 0

Table 4-2. Summary of Construction Information for Monitoring Wells in the Vicinity of the 200-UP-1 Operable Unit Treatability Test Site.

\begin{tabular}{|c|c|c|c|c|c|c|}
\hline $\begin{array}{l}\text { Hell No. } \\
\left.(290-)^{\prime}\right)\end{array}$ & $\begin{array}{l}\text { sereen } \\
\text { dismoter. } \\
\text { in. }\end{array}$ & Material & $\begin{array}{l}\text { Drill } \\
\text { depth, } \\
\text { ft }\end{array}$ & $\begin{array}{l}\text { sereenod } \\
\text { interval. } \\
\text { ft }\end{array}$ & $\begin{array}{l}\text { Depth to } \\
\text { water. } \\
\text { ft (Dates) }\end{array}$ & $\begin{array}{l}\text { sereened } \\
\text { woter } \\
\text { depth, ft }\end{array}$ \\
\hline W19-19 & 5 & ss & 257 & 230 to 250 & $238(05 / 93)$ & 11.8 \\
\hline N19-20 & 6 & $8 s$ & 252 & 231 to 251 & $235(00 / 93)$ & 16.1 \\
\hline H19-23 & 5 & ss & 256 & 253 to 253 & $243(12 / 93)$ & 10.1 \\
\hline N19-24 & 5 & ss & 255 & 231 to 251 & 241 (11/93) & 10.3 \\
\hline U19-25 & 5 & ss & 248 & 228 to 248 & $236(12 / 93)$ & 13.6 \\
\hline 419-26 & 5 & ss & 250 & 228 to 248 & $238(08 / 93)$ & 10.1 \\
\hline N19-29 & 4 & RRP & 256 & 234 to 255 & 265 (12/93) & 10.4 \\
\hline W19-30 & 4 & ss & 256 & 233 to 253 & $243(12 / 93)$ & 10.6 \\
\hline
\end{tabular}

Well construction information based on Ledgerwood (1992).

ss - stuinleas ateol

FRP = fibarglass-reinforeed plastic. 
DOE/RL-93-105

Rev. 0

Table 4-3. List of Analytes for Groundwater Monitoring.

\begin{tabular}{|c|c|c|l|}
\hline Analyte & Method & Holding Time & \multicolumn{1}{|c|}{ Bottle/Volume } \\
\hline $\begin{array}{l}\text { Radionuclides: } \\
\text { 99TC }\end{array}$ & EPA 901.1॰ & $6 \mathrm{mo}$ & Plastic, 2,000 mL \\
Uranium (tota1) & EPA 908* & $6 \mathrm{mo}$ & Plastic, 2,000 mL \\
Field nitrate & Field method & 14 days & Glass, 250 mL \\
\hline
\end{tabular}

- EPA 1982. 


\subsection{SUPPORTIME DOCUMENTS}

Supporting documents include the 200 West Groundwater AAMSR (DOE-RL 1992a) and the Renadial Investigation/Feasibility Study Work Plan for the 200-UP-1 Groundwater Operable Unit (DOE-RL 1993a). The work plan primarily defines an LFI program, but identifies and schedules a pilot-scale pump and treat test for the IRM plume. Supporting documents in the 200 West Groundwater AMSR (DOE-RL 1992a) include a health and safety plan, project management plan, and a data management plan. A National Environmental Policy Act categorical exclusion has been applied for all Hanford Site pilot-scale treatability testing. Additional supporting documents include a QAPJP in the work plan. These supporting plans will be applicable to all work scope performed by WHC within the 200-UP-1 Operable Unit.

Treatability test-spectfic operating procedures will be prepared to conduct the pilot-scale test. This plan refines quality assurance and sampling procedures/requirements outilined in the quality assurance project plan specific to the treatability test. Additional quality assurance procedures/requirements may be further refined in the operating procedures.

Community relation activities in support of this treatability test will be performed as specified in the Trt-Party Agreement (Ecology et al. 1989b). The WHC will prepare a hazardous waste operations permit, radiation work permit, and safety analysis plan prior to initiation of field activities.

The following task-specific documents/permits will be prepared.

- Hazardous waste operation permit: Addresses and mitigates sitespecific health and safety hazards, provides for emergency response and sets forth personnel training requirements necessary for site entry.

- Radiation work perwit: Addresses specific radiological control requirements for conducting the test.

- Safety analysis plan: Addresses global safety and environmental issues assoctated with plant operations (e.g., impacts resulting from tank fallure) and specifies appropriate safety requirements for mitigation of these impacts.

- Standard operating procedures: Establishes the process and procedures necessary for safe and effective operation of the treatment system. Identiffes steps to be followed in the performance of the treatability test with sufficient detail to allow the operator to operate the equipment and collect the samples with minimum supervision.

- A capture zone analysis to support selection of pumping and return wells. 
DOE/RL-93-105

Rev. 0

\subsection{REPORTS}

A treatability test report will be prepared summarizing the results of the laboratory and pllot-scale testing. The format of the report will be based on the suggested outline for treatability test reports provided in the Guide for Conducting Treatability studies under CERCLA (EPA 1992). The schedule for finalizing the treatability test report will be dependent on laboratory turn-around times for chemical analyses and may parallel the preparation and review of the IRM Proposed Plan. In addition, monthly project briefings will be given at unit manager meetings between DOE, EPA, and Ecology. 
DOE/RL-93-105

Rev. 0

\subsection{SCHEDULE}

Figure 7-1 shows a schedule for prerequisite tasks, and completing the treatability test and issuing a report. The planned start of the pilot-scale treatability test is March 31, 1994 pending approval of the 200-UP-1 Operable Unit work plan (DOE-RL 1993a). The overall 200-UP-1 Operable Unit schedule is provided in the work plan. The schedule is contingent on adequate well capacity, approval of the well recommendations and WCP, and that all safety concerns can be addressed. 


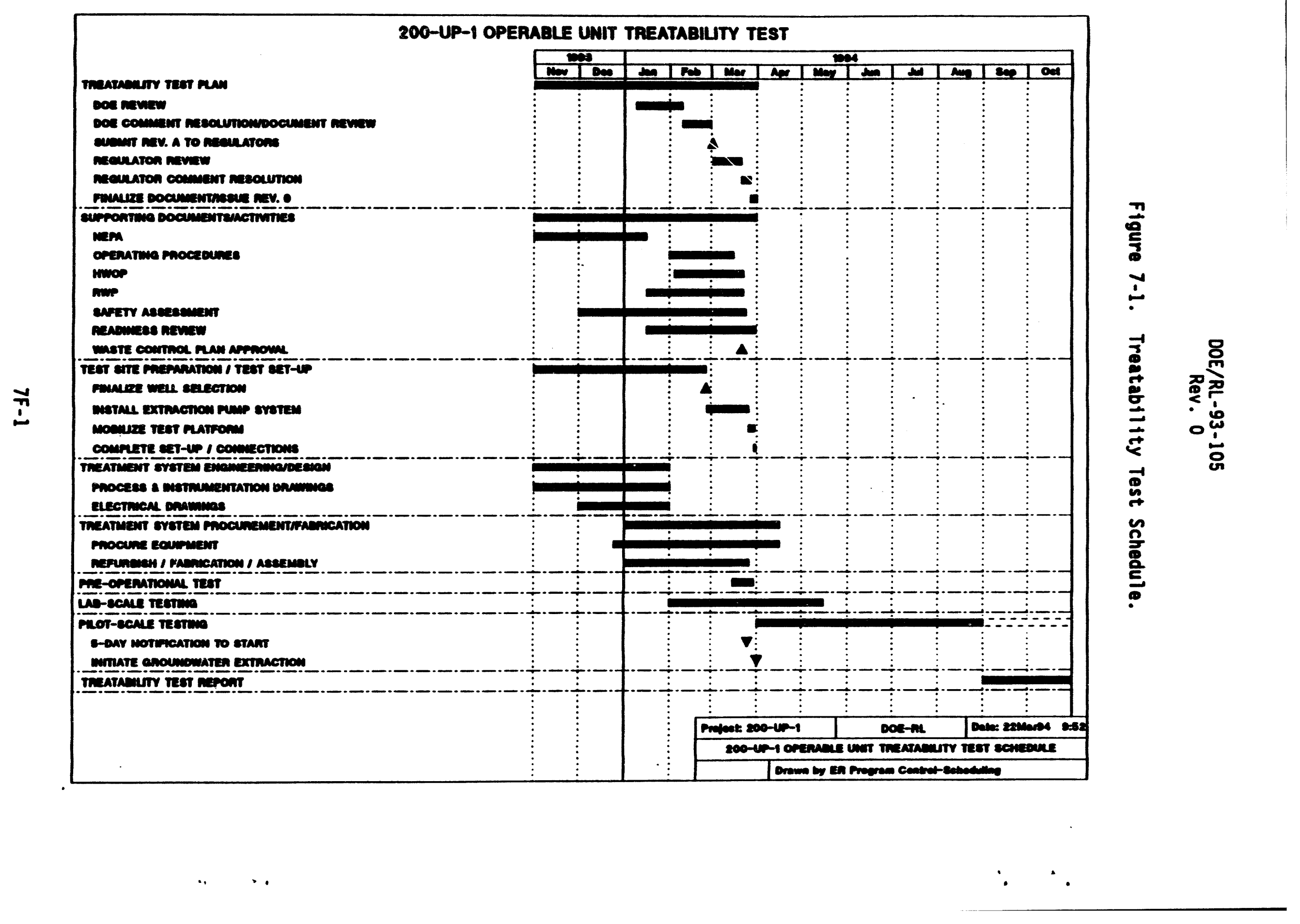


DOE/RL-93-105

Rev. 0

\subsection{PROgRAM ORGANIZATION}

The organization for performing tasks associated with the treatability test is shown graphically in Figure 8-1. The WHC Environmental Restoration Engineering organization will have direct responsibility for the planning, operation, and evaluation of the test, and the preparation of operational procedures. Other WHC organizations will provide support as needed. 
DOE/RL-93-105

Rev. 0

Figure 8-1. 200-UP-1 Operable Unit Groundwater Treatability Test.

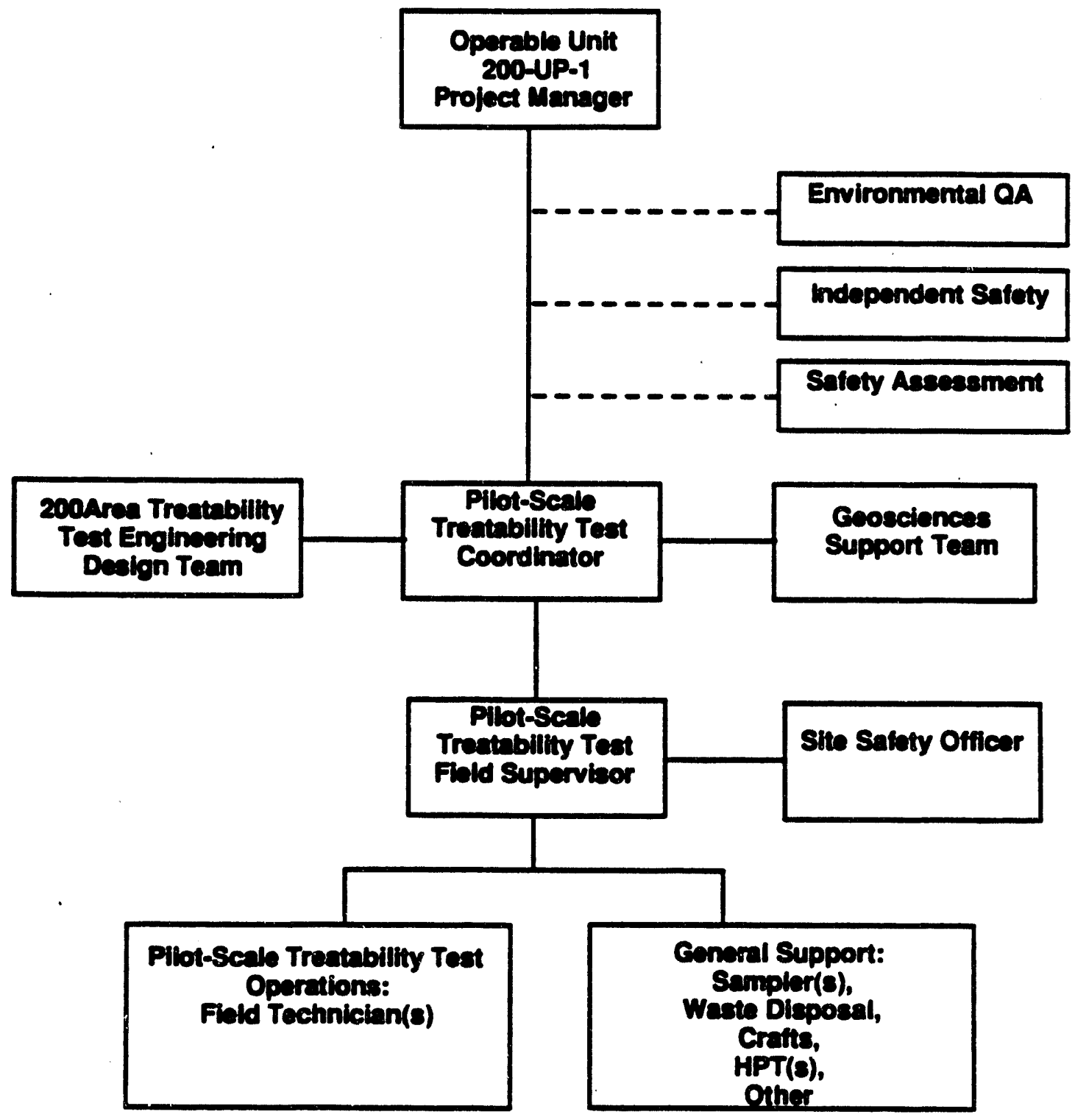


DOE/RL-93-105

Rev. 0

\subsection{REFERENCES}

Baker, S.M., J.L. Devary, R.P. Elmore, E.F. Lorang, A.J. Rossi, and M.D. Freshly, 1988, U1/U2 Uranium Plume Characterization, Remedial Action Review and Recomendation for Future Action, WHC-EP-0133, Westinghouse Hanford Company, Richland, Washington.

Barney, G.S., K.J. Lueck, and J.W. Green, 1992, Removal of Plutonium from LowLevel Process Wastewaters by Adsorption, "Environmental Remediation, Removing Organics and Metal Ion Pollutants," ACS Symposium Series 509, American Chemical Society, Washington D.C., Pp. 34-46.

Connelly, M.P., K.H. Lindsey, L. Borghese, and B.H. Ford, 1992, Hydrogeologic Model for 200 West Groundwater Aggregate Area, WHC-SD-EN-TI-014, Rev. 0, Westinghouse Hanford Company, Richland, Washington.

Connelly, M.P., 1994, Capture Zone Analyses for 200-ZP-1 and 200-UP-1 Pilot Scale Puap and Treat Tests, WHC-SD-EN-TI-252, Rev. 0, Westinghouse Hanford Company, Richland, Washington.

Del CuI, G.D., H.D. Bostick, D.R. Trotter, and P.E. Osborne, 1992, "Technetium-99 Removal from Process Solutions and Contaminated Groundwater,; In: Separation Science and Technology, 28(1-3), Pp. 551564.

Delegard, C.H., R.L. Weiss, R.T. Kimura, A.G. Law, and R.C. Routson, 1986, Characterization and Anion Exchange Removal of Uranium from Hanford Ground Water, RHO-RE-SA-116P, Rockwell Hanford Operations, Richland, Washington.

DOE-RL, 1991, Hanford Past-Practice Strategy, Revision 0, DOE/RL-91-40, U.S. Department of Energy, Richland, Washington.

DOE-RL, 1992a, 200 West Groundwater Aggregate Area Management Study Report, DOE/RL-92-16, U.S. Department of Energy, Richland, Washington.

DOE-RL, 1992b, U Plant Source Aggregate Area Management Study Report, DOE/RL-91-52, U.S. Department of Energy, Richland, Washington.

DOE-RL, 1993a, Remedial Investigation/Feasibility Study Work Plan for the 200-UP-1 Groundwater Operable Unit, Hanford Site, Richland, Washington, DOE/RL 92-76, U.S. Department of Energy, Richland Field Office, Richland, Washington.

DOE-P!, 1993b, Remedial Investigation/Feasibility Study Work Plan for the 200-UP-2 Source Operable Unit, Hanford Site, Richland, Washington, DOE/RL 91-19, U.S. Department of Energy, Richland Field Office, Richland, Washington. 
DOE-RL, 1994, Hanford Environmental Information System (HEIS): Volume 1 User's Guide, DOE/RL-93-24-1, U.S. Department of Energy, Richland Operations, Richland, Washington.

Ecology, EPA, and DOE, 1989a, et seq, Hanford Federal Facility Agreement and Consent Order, 2 Vols., Washington State Department of Ecology, U.S. Protection Agency, and U.S. Department of Energy, Olympia, Washington.

Ecology, EPA, and DOE, 1989b, Community Relations Plan for the Hanford Federal Facility Agreement and Consent Order, Washington State Department of Ecology, U.S. Protection Agency, and U.S. Department of Energy, Olympia, Washington.

Ecology, EPA, and DOE, 1994, Hanford Federal Facility Agreement and Consent Order, Fourth Amendment, Washington State Department of Ecology, U.S. Protection Agency, and U.S. Department of Energy, Olympia, Washington.

EPA, 1982, Preseribed Procedures for the Measurement of Radioactivity in Drinking Water, EPA-600/4-80-032, U.S. Environmental Protection Agency/Environmental Monitoring and Support Laboratory, Cincinnat1, Ohio.

EPA, 1986, Test Methods for Evaluating Solid Waste (SW-846), Third Edition, U.S. Environmental Protection Agency, Office of Solid Waste and Emergency Response, Washington, D.C.

EPA, 1987, Data Quality Objectives for Remedial Response Activities-Development Process, EPA/540-G-87/003 and 004, OSWER Directive 9335.3-01, U.S. Environmental Protection Agency, Washington, D.C.

EPA, 1990, Assessment of Technologies for the Remediation of Radioactively Contaninated Superfund Sites, EPA/s40/2-90/001, U.S. Environmental Protection Agency, Washington, D.C.

EPA, 1991a, USEPA Contract Laboratory Program Statement of Work for Inorganics Analysis: Multi-Media Multi-Concentration, U.S. Environmental Protection Agency, Sample Management Laboratory, Washington, D.C.

EPA, 1991b, USEPA Contract Laboratory Program Statement of Work for Organics Analysis: Multi-Media Multi-Concentration, U.S. Environmental Protection Agency, Sample Management Laboratory, Washington, D.C.

EPA, 1992, Guide for Conducting Treatability Studies under CERCLA, Final, EPA 540/R-92/071a, U.S. Environmental Protection Agency, Washington, D.C., October, 1992.

Jelinek, R.T., and T.J. Sorg, 1988, "Operating a Small Full-Scale Ion Exchange System for Uranium Removal" in Journal American Water Works Association, Volume 80, No. 7, Pp. 79-83.

Kasza, G.L., M.J. Hartman, F.N. Hodges, K.R. Simpson, and D.C. Heekes, 1993, Groundwater Maps of the Hanford Site, December 1992, WHC-EP-0394-6, Westinghouse Hanford Company, Richland, Washington. 
Kopp, J.F., and G.D. McKee, 1983, Methods for Chemical Analysis of Water and Wastes, EPA-600/4-79-020, U.S. Environmental Protection Agency, Environmental Monitoring and Support Laboratory, Washington, D.C.

Lindah1, P.C., 1984, Determination of Inorganic Anions in Aqueous and Solid Samples of Ion Chromatography, EPA/600/4-84/017, Argonne National Laboratory, Argonne, Illinois.

Ledgerwood, R.K., 1992, Summaries of Well Construction Data and Field Observations for Existing 200-West Resource Protection Wells, WHC-SD-ER-TI-005, Rev. 0, Westinghouse Hanford Company, Richi and, Washington.

McCain, R.G. and W.L. Johnson, 1990, A Proposal Data Quality Strategy for Hanford Site Characterization, WHC-SD-EN-AP-023, Westinghouse Hanford Company, Richland, Washington.

Newcomer, D.R., M.A. Chamness, D. L. McAllister, R. J. Brockman, 1992, Unconfined Aquifer Hydrologic Test Data Package for the 200 Areas Groundwater Aggregate Area Management Studies, WHC-SD-EN-DP-031, Rev. O, Westinghouse Hanford Company, Richland, Washington.

Robinson, S.M., 1990, Strategy for Management of Oak Ridge National Laboratory (ORVL) Process Wastewater, Draft, Mart in Marfetta Energy Systems, Oak Ridge, Tennessee.

Simpson, K.R., 1994, Data for Well Useability Tests in Support of 200-UP-1 Treatability Program, WHC-SD-EN-DP-083, Westinghouse Hanford Company, Richland, Washington.

Sorg, T.J., 1989, Removal of Uranium from Drinking Water by Conventional Treatment Methods, EPA/600/D-89/020, Drinking Water Research Division, Risk Reduction Engineering Laboratory, U.S. Environmental Protection Agency, Cincinnati, Ohio.

Sorg, T.J., 1991, Radionuclide Rewoval, EPA/600/D-91/262, Drinking Water Research Division, Risk Reduction Engineering Laboratory, U.S. Environmental Protection Agency, Cincinnati, Ohio.

WHC, 1987, Industrial Safety Manual, Vol. I through 3, WHC-CM-4-3, Westinghouse Hanford Company, Richland, Washington.

WHC, 1988a, Standard Engineering Practices, WHC-CM-6-1, Westinghouse Hanford Company, Richland, Washington.

WHC, 1988b, Environmental Investigations and Site Characterization Manual, WHC-CM-7-7 Westinghouse Hanford Company, Richland, Washington.

WHC, 1988c, Quality Assurance Manual, WHC-CM-4-2, Westinghouse Hanford Company, Richiand, Washington. 
WHC, 1988d, Health Physics Practices Manual, WHC-CM-4-12, Westinghouse Hanford Company, Richland, Washington.

WHC, 1988e, Environmental Compliance Manual, WHC-CM-7-5, Westinghouse Hanford Company, Richland, Washington.

WHC, 1990, Environmental Engineering, Technology, and Permitting Function Quality Assurance Program Plan, WHC-EP-0383, West inghouse Hanford Company, Richland, Washington.

WHC, 1992, Environmental Engineering and Geotechnology Function Procedures, WHC-CM-7-8, Volume 4, Westinghouse Hanford Company, Richland, Washington.

WHC, 1993, Westinghouse Radiological Control Manual, WHC-CM-1-6, Westinghouse Hanford Company, Richl and, Washington.

WHC, 1994, Treatment Tests for Ex Situ Removal of Chromate, Nitrate, and Uranium(VI) from Hanford (100-HR-3) Groundwater Final Report, WHC-SD-ER-DTR-001, Rev. 0, Westinghouse Hanford Company, Richland, Washington. 
DOE/RL-93-105

Rev. 0

APPENDIX A

200-UP-1 OPERABLE UNIT TREATABILITY TEST

WASTE CONTROL PLAN 
DOE/RL-93-105

Rev. 0

\section{APPENDIX A}

\section{0-UP-1 OPERABLE UNIT TREATABILITY TEST WASTE CONTROL PLAN}

This appendix presents the method by which wastes generated during implementation of the 200-UP-1 treatability tests will be controlled. This plan addresses those waste generated during implementation of the field portion of the test. Wastes generated during the lab scale portion will be handled using standard laboratory procedures.

Wastes generated during implementation of the field treatability tests are to be managed in accordance with WHC-CM-7-7, EII 4.3, Control of CERCLA and other Past-Practice Investigation Derived Waste and this plan. Regulatory agreement will be obtained if deviations from this procedure are necessary. Site specific waste handling methods are provided below.

The generation of radiological wastes during implementation of the field portion of the treatability tests is expected as Uranium and ${ }^{\circ} \mathrm{Tc}$ are to be removed from the groundwater and collected on ion-exchange resins. This waste is not expected to be hazardous as the ion exchange resins identified are not designated as hazardous and should not retain any hazardous constituents. All waste materials having the potential for containing radiological constituents will be field screened using portable radiological monitoring equipment. Waste determined to be radiologically contaminated will be handled in accordance with WHC-CM-7-7, EII 4.3.

Waste types will be segregated to the extent practicable. For example, radiological trash such as disposable gloves, tape, plastic and other items used for radiological control purposes will be placed in separate containers from that of the ion exchange media.

The fon exchange media and any other treatment system wastes will be placed into separate containers. These wastes will be de-watered prior to placement in the waste drums. The liquids generated during the de-watering process, will be returned to the treatment systems influent tank. This liquid should not contain high levels of radionuclides as they will remain fixed to the ion exchange resin. Waste liquids not returned to the influent tank will be stabilized as identified in EII 4.3.

All wastes will be labeled in accordance with applicable procedures and regulations for storage. An on-site storage location will be selected for temporary storage of these wastes. The treatment system derived wastes may be relocated to a central waste container storage facility currently housing all the 200-UP-2 investigation derived waste.

All wastes, excluding the trash, will be sampled for waste designation purposes. These samples will be analyzed for the analytes identified in Table A-1. 
DOE/RL-93-105

Rev. 0

Figure A-1. Proposed Site PIan for the 200-UP-1

Operable Unit Treatability Test.

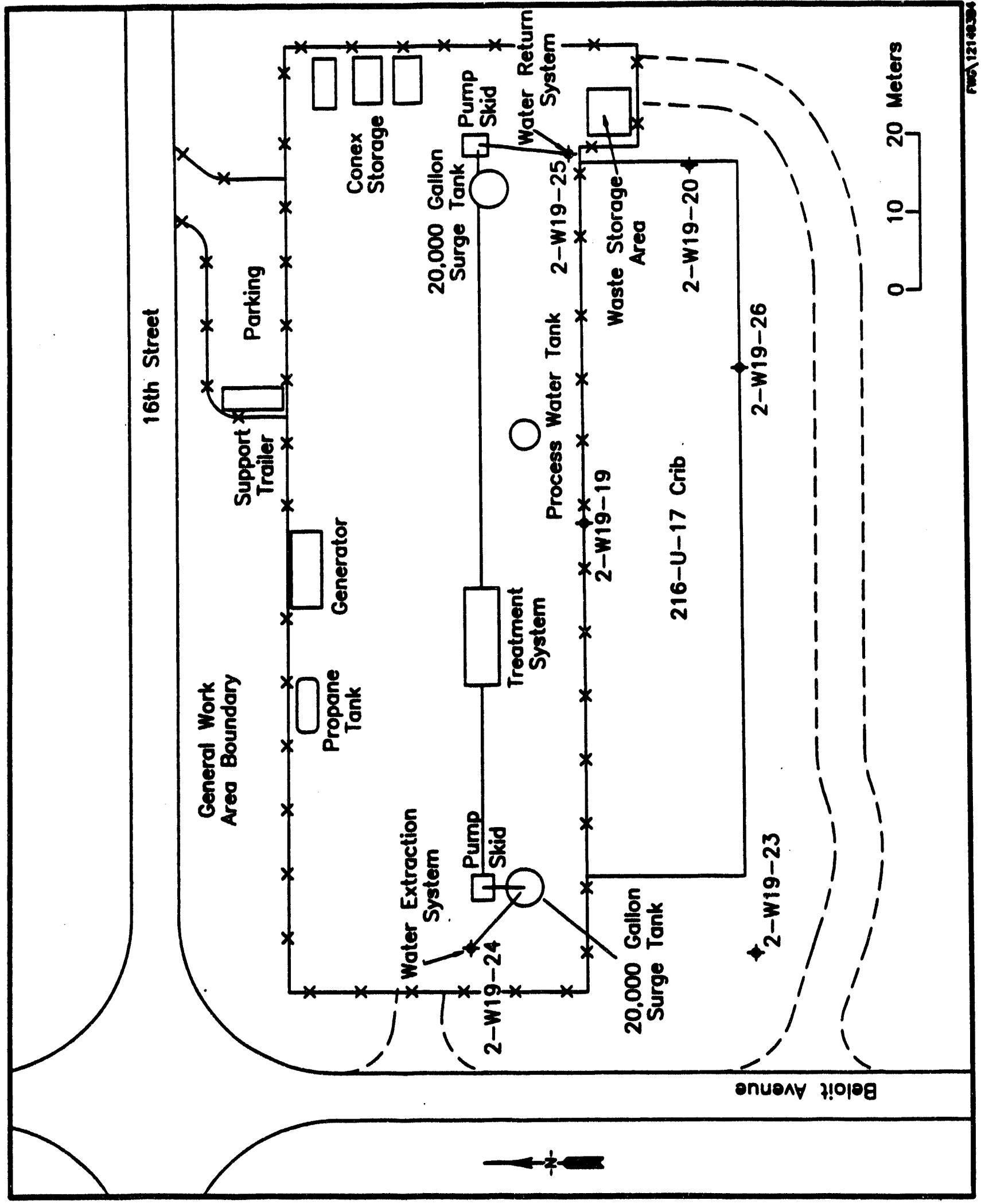


DOE/RL-93-105

Rev. C

Figure A-2. Location of Centralized Waste Container Storage Area for the 200-UP-2 Operable Unit, Located East of the 216-U-12 Crib, 200 West Area.

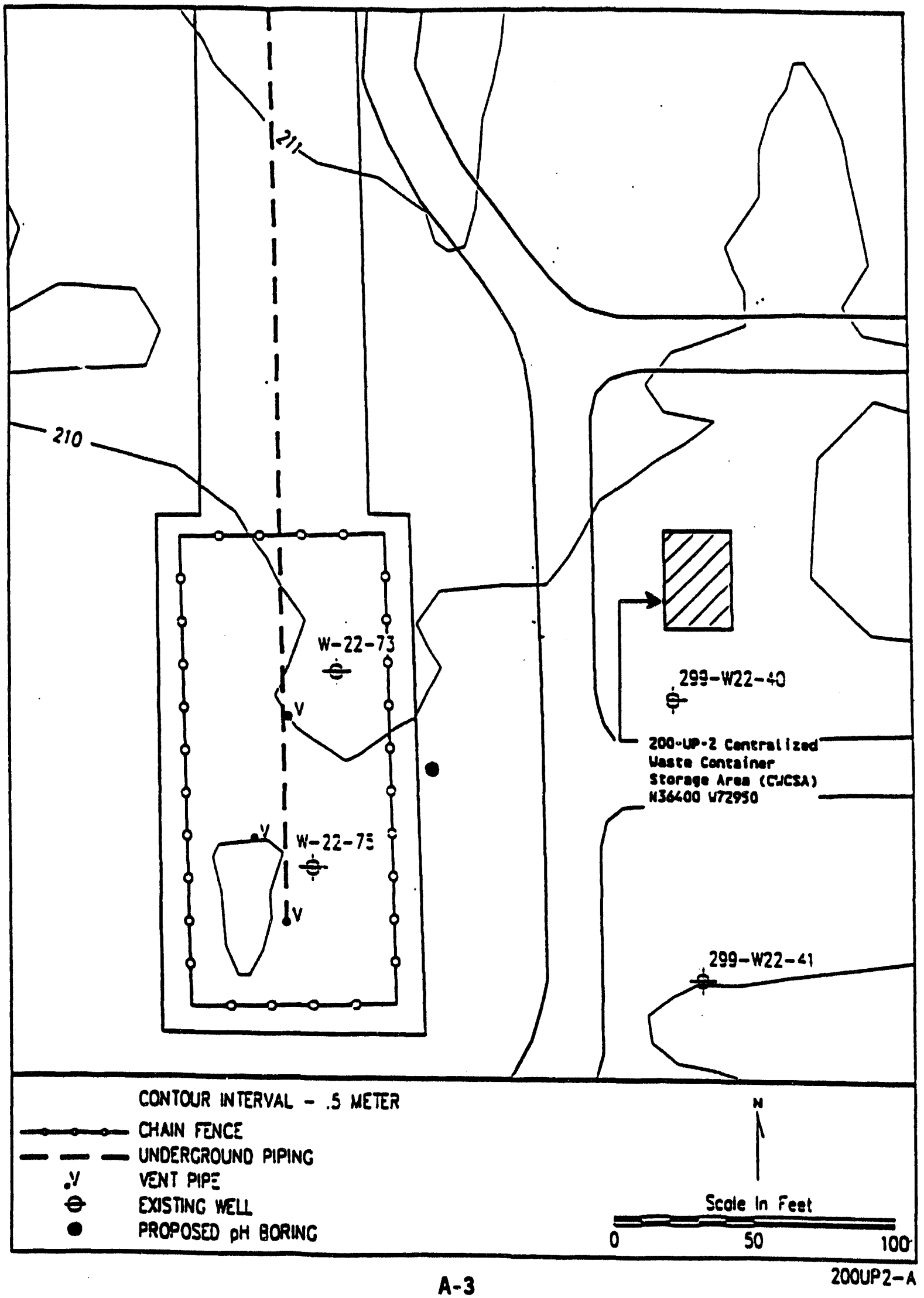


DOE/RL-93-105

Rev. 0

Table A-1. Waste Designation Analytes.

\begin{tabular}{|c|c|c|c|}
\hline Category of Analysis & Analytical Method & $\begin{array}{c}\text { Analytical } \\
\text { Level }\end{array}$ & Holding Time \\
\hline $\begin{array}{l}\text { Gross alpha } \\
\text { Gross beta } \\
\text { Gamma Spectrometry }\end{array}$ & $\begin{array}{c}\text { SW-846/9310 } \\
\text { SW-846/9310 } \\
\text { EPA 901.1 } \\
\end{array}$ & $\begin{array}{l}v \\
v \\
v \\
\end{array}$ & $\begin{array}{l}6 \text { months } \\
6 \text { months } \\
6 \text { months } \\
\end{array}$ \\
\hline ICP Metals & $S W-846 / 6010$ & III & 6 months \\
\hline $\begin{array}{c}\text { AA Metals } \\
\text { As } \\
\mathrm{Pb} \\
\mathrm{Se} \\
\mathrm{TI} \\
\mathrm{Hg}\end{array}$ & $\begin{array}{l}\text { SW-846/7060 } \\
\text { SW-846/7420 } \\
\text { SW-846/7740 } \\
\text { SW-846/7840 } \\
\text { SW-846/7471 } \\
\end{array}$ & $\begin{array}{l}\text { III } \\
\text { III } \\
\text { III } \\
\text { III } \\
\text { III }\end{array}$ & $\begin{array}{l}6 \text { months } \\
6 \text { months } \\
6 \text { months } \\
6 \text { months } \\
28 \text { days }\end{array}$ \\
\hline Semivolatiles & SH-846/8270 & III & 7 days \\
\hline VOA & $S H-846 / 8240$ & III & 10 days \\
\hline $\begin{array}{c}\text { Antons } \\
\mathrm{Cl}, \mathrm{PO}_{4} \\
\mathrm{NO}_{2}-\mathrm{NO}_{3} \\
\end{array}$ & $\begin{array}{l}\text { EPA } 300.0 \\
\text { EPA } 353.2 \\
\end{array}$ & $\begin{array}{l}n / a \\
n / a\end{array}$ & $\begin{array}{l}28 \text { days } \\
28 \text { days } \\
\end{array}$ \\
\hline Total Activity & $\begin{array}{l}\text { LA-548-111 } \\
\text { LA-508-121 }\end{array}$ & $n / a$ & ASAP \\
\hline
\end{tabular}


DOE/RL-93-105

ReV. 0

APPEDIX 8

200-UP-1 OPERBLE UNIT TREATABILITY TEST

PROCESS SNMPLINO NO NULYSIS PLN 
DOE/RL-93-105

Rev. 0

\section{APPEDIX B \\ 200-UP-1 OPERABLE UNIT TREATABILITY TEST \\ PROCESS SAMPLING AND NMLYSIS PLAN}

As discussed in the test objectives (Section 3.0), the primary focus of process sampling actiyities will be to determine overall process efficiency in removing uranium and PT. Nitrate removal efficiency will also be determined although nitrates are not a primary contaminant for the field treatability test. Data obtained from the sampiling effort may also provide useful information for optimizing the treatment process. All sampling activities must conform with the following:

- MHC-EP-0383, Environmental Engineering, Technology, and Permitting Function Quality Assurance Program Plan (WHC 1990)

- WHC-CH-1-6, Westinghouse Radiological Control Manual (WHC 1993)

- MHC-CM 4-3, Industrial Safety Manual (WHC 1987)

- WHC-CH-7-5, Environmental Compliance Manual (WHC 1988a)

- WHC-CM-7-7, Environmental Investigations and Site Characterization Manual (WHC 1988b)

- MHC-CM-7-8, Volume 4, Environmental Engineering and Geotechnology Function Procedures (WHC 1992)

- Site-specific hazardous waste operations permit

- Site-specific radiation work permit

- Project-specific safety assessment.

MHC manuals (1988b and 1992) contain the specific sampling procedures to be followed during all process sampling activities. The Environmental Investigation and Site Characterization Manual (WHC 1988b) also provides specific procedures for sample packaging and shipping, chain of custody, and storage.

Field screening sampling results (Level I and II analyses), will be used for making real-time operational decisions. Field screening sampling activities have significantly fewer procedural requirements in comparison with the offsite laboratory analytical requirements. This allows for a relatively nonrestrictive sampling approach required for operation of the treatment equipment. Analytical Level III and $V$ analyses (excluding field screening methods used for radionuclides), referred to as offsite laboratory analyses, will be used to confirm screening level analyses and to determine process removal efficiencies for uranium and "Tc. Table B-1 provides sampling and procedural parameters for these confirmatory analyses. 
DOE/RL-93-105

Rev. 0

A proposed sampling location/schedule/analyte list for the sampling activities has been developed and is described below. The information proposed for the field screening analysis is subject to change as necessary for optimal operation of the treatment system. All changes to the offsite laboratory sampling strategy will be documented on a field sampling change authorization form.

\section{SAMPLE LOCATION/SCHEDULE}

Sampling points are provided to monitor the pretreatment influent and effluent streams and ton exchange treatment influent and effluent streams as shown in Figure 4-2. Influent and effluent treatment samples for offsite laboratory analyses will be collected from location SC-4 and SC-12.

Offsite laboratory analysis samples will be taken at a minimum frequency of once per week. Additional samples may be taken during the first 2 weeks of steady-state, online operation. Additional samples may al so be taken when contaninant breakthrough in the primary ion exchange column is anticipated. The saupling will be performed at a time when steady-state operating conditions (as determined by field screening analysis and the operational log) have been reached.

The timing of the sampling effort will be such that the same volume of water is being saapled during each phase of the treatment process. For example, the design residence time in the ion exchange portion of the treatment system is approximately $16 \mathrm{~min}$. This means that the fon exchange system effluent sample will be obtained approximately 16 min after the influent sample is taken assuming the system is operating at design capacity.

Field screening analysis used to monitor and control the treatment process includes the use of online monitoring systems. These systems include pH, turbidity, and dissolved oxygen monitors. An onl ine uranium monitor may also be demonstrated during the operation of the system, if available. All online monitors will be operated and calibrated in accordance with the manufacturer's procedures.

As a minimum, additional screening analyses will be made for the following constituents:
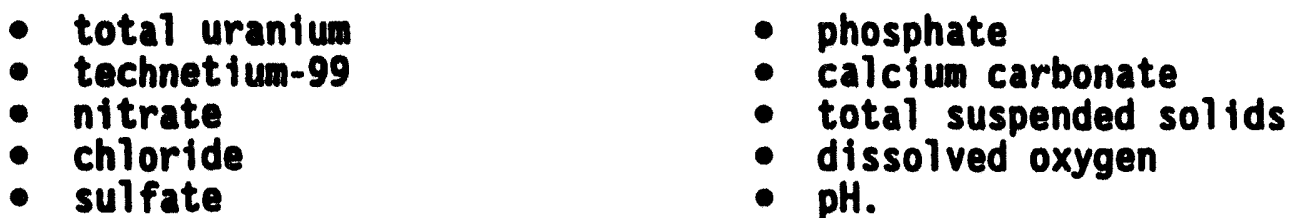

These analyses require that samples be taken from the treatment system on a routine basis, as necessary, for operation of the system. Specific sampling locations have been identified in Figure 4-2. Additional sample locations may 
DOE/RL-93-105

Rev. 0

be included as determined by the cognizant engineer, operator, or field team leader.

All field screening analyses, excluding the radionuclide analysis, will be performed in accordance with the manufacturer's procedures for the analyte of interest. Radionuclide field screening analyses will be performed in an onsite counting laboratory according to the laboratory's standard operating procedures. Any residual field screening sample material will be returned to the influent end of the process system for treatment.

Waste designation samples will also be taken as required for disposal of spent resins and discarded filter cartridges. Additional waste streams, such as residuals generated as a result of the addition of $\mathrm{pH}$ controlining chemicals, may also require sampling. The sample analysis requirements for waste designation are documented in the waste control plan (Appendix A). The results of these analyses will be recorded in the field log book.

\section{QUALITY ASSURANCE/QUALITY CONTROL REQUIREMENTS}

To ensure data quality, all offsite laboratory sampling activities will be performed in accordance with the procedures identified in this operational sampling plan. The quality control of the sampling and laboratory analysis activities will be verified through the use of duplicate and split samples. A maximum of one duplicate and one split sample will be taken for every four offsite laboratory samples taken.

Mon-online monitoring field screening data quality will be performed through the analysis of duplicate samples and by following the recommended calibration verification methods identified in the manufacturer's procedures manual for the avalyte in question. For each separate analysis, a minimum of one duplicate sample will be analyzed for every 20 samples taken. Data obtained from online monitoring equipment will be controlled by adherence to the manufacturers operating instructions.

All quality assurance level III and $V$ analytical methods (excluding field screening analysis for radionuclides) will be performed in accordance with Table QAPJP-1 in Appendix A of the Remedial Investigation/Feasibility Study Work Plan for the 200-UP-1 Groundwater Operable Unit, Hanford Site, Richland, Washington (DOE-RL 1993).

\section{REFERENCES}

EPA, 1982, Prescribed Procedures for the Measurement of Radioactivity in Drinking Water, EPA-600/4-80-032, U.S. Environmental Protection Agency/Environmental Monitoring and Support Laboratory, Cincinnati, Ohio. 
Kopp, J. F., and G. D. McKee, 1983, Methods for Chemical Analysis of Water and Wastes, EPA-600/4-79-020, U.S. Environmental Protection Agency, Environmental Monitoring and Support Laboratory, Washington, D.C.

Lindahl, P. C., 1984, Determination of Inorganic Anions in Aqueous and Solid Samples of Ion Chromatography, EPA/600/4-84/017, Argonne National Laboratory, Argonne, Illinois.

WHC, 1987, Industrial Safety Manual, Vol. 1 through 3, WHC-CM-4-3, Westinghouse Hanford Company, Richland, Washington.

WHC, 1988a, Environmental Compliance Manual, WHC-CM-7-5, Westinghouse Hanford Company, Richland, Washington.

WHC, 1988b, Radiation Protection, WHC-CM-4-10, Westinghouse Hanford Company, Richland, Washington.

WHC, 1993, Westinghouse Radiological Control Manual, WHC-CM-1-6, Westinghouse Hanford Company, Richland, Washington. 
DOE/RL-93-105

Rev. 0

Table B-1. 200-UP-1 Pilot-Scale Treatability Test Offsite Sample Analytical Parameters.

\begin{tabular}{|c|c|c|c|}
\hline Category of Analysis & Analytical Method & $\begin{array}{c}\text { Analytical } \\
\text { Level }\end{array}$ & Holding Time \\
\hline $\mathrm{NO}_{2}-\mathrm{NO}_{3}$ & $\begin{array}{c}\text { EPA } 300 \text { Modified } \\
\text { EPA } 354.1^{\mathrm{b}}, \\
\text { EPA } 352.1^{\mathrm{b}} \\
\text { EPA } 353.3^{\mathrm{b}}, \\
\text { EPA } 353.2^{\mathrm{b}}\end{array}$ & NA & 28 days \\
\hline Total Activity & $\begin{array}{l}\text { LA-548-111 } \\
\text { LA-508-121 }\end{array}$ & NA & ASAP \\
\hline Uranium (total) & EPA $908^{d}$ & v & 6 months \\
\hline${ }^{90} \mathrm{TC}$ & EPA $901.1^{d}$ & $v$ & 6 months \\
\hline
\end{tabular}

- Method specified is from Determination of Inorganic Anions in Aqueous and Solid Samples of Ion Chromatography (Lindahl 1984), and is a modification of EPA Method 300.0.

b Methods for Chemical Analysis of Water and Wastes (Kopp and McKee 1983).

C MHC laboratory analytical procedures.

- Prescribed Procedures for the Measurement of Radioactivity in Drinking Water (EPA 1982).

MA = Not applicable.

ASAP = As soon as possible. 
Metric Conversion Chart

The following conversion chart is provided to the reader as a tool to aid in conversion.

\begin{tabular}{|c|c|c|c|c|c|}
\hline \multicolumn{3}{|c|}{ Into Metric Units } & \multicolumn{3}{|c|}{ Out of Metric Units } \\
\hline $\begin{array}{l}\text { If You Know. } \\
\text { Length }\end{array}$ & Muttiply By & To Got & $\begin{array}{l}\text { If You Know } \\
\text { Length }\end{array}$ & Muttioly By & To Got \\
\hline inches & 25.4 & millimeters & millimeters & 0.039 & inches \\
\hline inches & 2.54 & centimeters & centimeters & 0.394 & inches \\
\hline feet & 0.305 & moters & meters & 3.281 & feet \\
\hline yards & 0.914 & moters & meters & 1.094 & yards \\
\hline miles & 1.609 & kilometers & kllometers & 0.621 & miles \\
\hline Area & & & Area & & \\
\hline sq. inches & 6.452 & sq. centimeters & sq. centimeters & 0.155 & sq. inches \\
\hline sq. feet & 0.093 & sq. meters & sq. moters & 10.76 & sq. feet \\
\hline sq. Yards & .0836 & sq. moters & sq. moters & 1.196 & sq. yards \\
\hline sq. miles & 2.6 & sq. kilometers & sq. kilometers & 0.4 & sq. miles \\
\hline acres & 0.405 & hectares & hectares & 2.47 & acres \\
\hline Mass (woig & & & Mass (woight) & & \\
\hline ounces & 28.35 & orams & orams & 0.035 & ounces \\
\hline pounds & 0.454 & kilograms & kilograms & 2.205 & pounds \\
\hline short ton & 0.907 & metric ton & matric ton & 1.102 & short ton \\
\hline Volume & & & Volume & & \\
\hline teaspoons & 5 & milliliters & millilters & 0.033 & fluid ounces \\
\hline tablespoons & 15 & milliliters & liters & 2.1 & pints \\
\hline fluid ounces & 30 & milliliters & Iiters & 1.057 & quarts \\
\hline cups & 0.24 & liters & Iiters & 0.264 & gallons \\
\hline pints & 0.47 & Iiters & cuble meters & 35.315 & cuble feet \\
\hline quarts & 0.95 & liters & cubic meters & 1.308 & cuble yards \\
\hline gallons & 3.8 & Iiters & & & \\
\hline cuble feet & 0.028 & cubic moters & & & \\
\hline cuble yards & 0.765 & cubic meters & & & \\
\hline Temperatur & & & Temperature & & \\
\hline Fahrenheit & $\begin{array}{l}\text { subtract } \\
32 \text {, then } \\
\text { multiply by } \\
5 / 9\end{array}$ & Celsius & Celsius & $\begin{array}{l}\text { muktiply by } \\
9 / 5 \text {, then } \\
\text { add } 32\end{array}$ & Fahrenhedt \\
\hline
\end{tabular}


DOE/RL-93-105, Rev. 0

\section{DISTRIBUTION}

\section{Number of Copies}

Onsite

31

U.S. Department of Energy, Richland Field office

J. K. Erickson (30)

A5-19

Public Reading Room

Al-65

1

Pacific Northwest Laboratory

Hanford Technical Library

P8-55

30

Westinghouse Hanford Company

L. D. Arnold

B2-35

P. J. Mackey

C. D. Wittreich (14)

Central Files (2)

EPIC (2)

ERC (G. Fitzgibbon)

ERE (L. Hermann) (2)

ERE Project File

ER Program Office (2)

IRA (3)

Resource Center

B3-06

H6-03

L8-04

H6-08

H6-07

H6- 07

H6-03

H6-27

$\mathrm{H} 4-17$

N3-05

Distr-1 

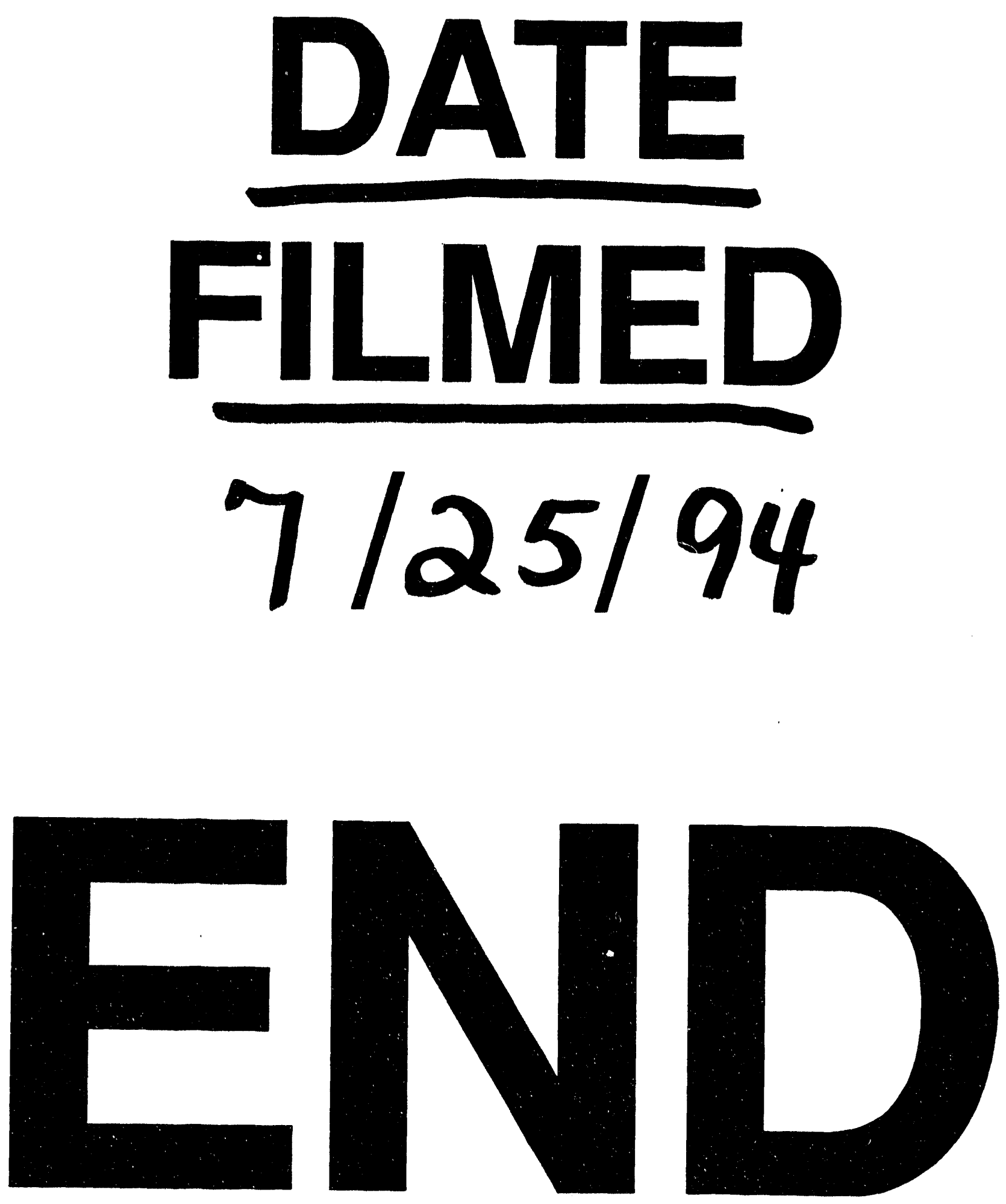
